DIW BERLIN

Discussion

Papers
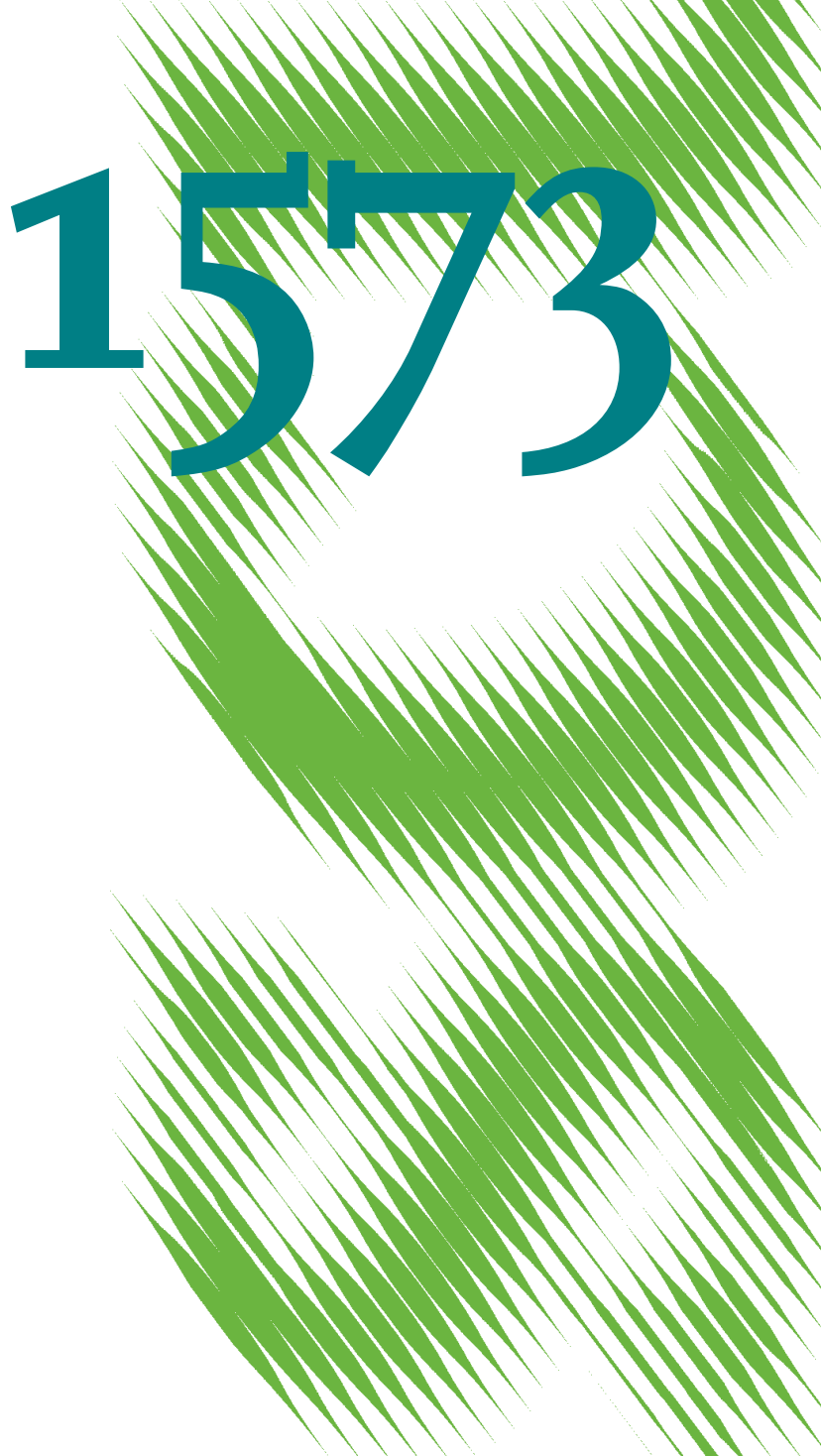

Calendar Anomalies in the Ukrainian Stock Market 
Opinions expressed in this paper are those of the author(s) and do not necessarily reflect views of the institute.

IMPRESSUM

(C) DIW Berlin, 2016

DIW Berlin

German Institute for Economic Research

Mohrenstr. 58

10117 Berlin

Tel. +49 (30) $89789-0$

Fax +49 (30) $89789-200$

http://www.diw.de

ISSN electronic edition 1619-4535

Papers can be downloaded free of charge from the DIW Berlin website:

http://www.diw.de/discussionpapers

Discussion Papers of DIW Berlin are indexed in RePEc and SSRN:

http://ideas.repec.org/s/diw/diwwpp.html

http://www.ssrn.com/link/DIW-Berlin-German-Inst-Econ-Res.html 


\title{
Calendar Anomalies in the Ukrainian Stock Market
}

\author{
Guglielmo Maria Caporale* \\ Brunel University London, CESifo and DIW Berlin
}

Alex Plastun

Sumy State University

April 2016

\begin{abstract}
This paper is a comprehensive investigation of calendar anomalies in the Ukrainian stock market. It employs various statistical techniques (average analysis, Student's t-test, ANOVA, the Kruskal-Wallis test, and regression analysis with dummy variables) and a trading simulation approach to test for the presence of the following anomalies: Day of the Week Effect; Turn of the Month Effect; Turn of the Year Effect; Month of the Year Effect; January Effect; Holiday Effect; Halloween Effect. The results suggest that in general calendar anomalies are not present in the Ukrainian stock market, but there are a few exceptions, i.e. the Turn of the Year and Halloween Effect for the PFTS index, and the Month of the Year Effect for UX futures. However, the trading simulation analysis shows that only trading strategies based on the Turn of the Year Effect for the PFTS index and the Month of the Year Effect for the UX futures can generate exploitable profit opportunities that can be interpreted as evidence against market efficiency.
\end{abstract}

Keywords: Calendar Anomalies; Day of the Week Effect; Turn of the Month Effect; Month of the Year Effect; January Effect; Holiday Effect; Halloween Effect.

JEL classification: G12, C63

${ }^{*}$ Corresponding author. Research Professor at DIW Berlin. Department of Economics and Finance, Brunel University London, UB8 3PH, United Kingdom. Email: Guglielmo-Maria.Caporale@brunel.ac.uk 


\section{Introduction}

Stock markets often exhibit a variety of so-called calendar anomalies, including the Day of the Week Effect, the Turn of the Month Effect, the Month of the Year Effect, the January Effect, the Holiday Effect, the Halloween Effect etc. These have been extensively analysed in numerous empirical studies providing mixed evidence. However, to date no comprehensive study has been carried out for Ukraine. The present paper aims to fill this gap by using various statistical techniques (average analysis, parametric tests such as Student's t-test and ANOVA analysis, non-parametric techniques such as the Kruskal Wallis test, regression analysis with dummy variables) to test for the presence of calendar anomalies in the Ukrainian stock market. To establish whether such effects are not just statistical anomalies but can be exploited by adopting appropriate trading strategies, we employ a trading simulation approach. To reduce the possibility of data-mining three different indices (UX Index, PFTS Index, Futures for the UX Index) are used.

The layout of the paper is as follows. Section 2 briefly reviews the most common calendar anomalies and the available evidence. Section 3 describes the data and outlines the empirical methodology. Section 4 presents the empirical results. Section 5 offers some concluding remarks.

\section{Calendar Anomalies}

The most frequently observed calendar anomalies and the evidence for them are discussed below.

The Day-of-the-Week effect (the Weekend effect, the Monday effect) implies that the distribution of stock returns is different for different days of the week. For example Cross (1973) analysed the Standard \& Poor's Composite Stock Index data from January 1953 to December 1970 and claimed to have found some patterns in the behaviour of US asset prices, namely an increase on Fridays and a decrease on Mondays. 
The Turn of the Month Effect was reported, among others, by Ariel (1987), who found that returns on the last and the first four trading days are higher than on other days of the month. Different event windows have been used in the literature. The most common nowadays is $(-1 ;+3)$.; for example, Lakonishok and Smidt (1988) analysed US stocks over a period of 90 years and found that cumulative returns in the four days between the last trading day of the month and the following three trading days exceeded returns over the entire month.

The Turn of the Year Effect amounts to stock returns in the last week of December and the first two weeks of January being higher than returns at other times of the year. For instance, Clark and Ziemba (1987) found that on the last trading days in December and on the first eight trading days in January stock returns are higher (see also the seminal study by Rozeff and Kinney, 1976).

The Month of the Year Effect and the January Effect are found when returns vary depending on the month of the year, with January exhibiting higher returns, as reported, for instance, by Wachtel (1942) for the Dow Jones Industrial Average over the time period 1927-1942. Rozeff and Kinney (1976) also provided similar evidence. The so-called Mark Twain Effect is observed when stock returns are lower in October than in other months.

The Holiday Effect implies that pre-holiday average returns are higher than postholiday returns. For example, Ariel (1990) showed that they are on average eight times higher than the (usually negative) post-holiday returns; Lakonishok and Smidt (1988), analysing ninety years of data on the Dow Jones Industrial Average index, calculated that the pre-holiday rate of return is 23 times larger than the normal daily rate of return.

The Halloween Effect is characterised by the period from November to April inclusive having significantly stronger average growth than the other months. It is based on the investment strategy "Sell in May and go away", following which stocks are sold at the 
start of May and bought again in the autumn. Jacobsen and Bouman (2002) showed that such a strategy can generate abnormal returns.

It is noteworthy that calendar anomalies might be fading. For example Fortune (1998, 1999), Schwert (2003), and Olson et al. (2010) argue that the weekend effect has become less important over the years. More details on previous studies are provided in Appendix A.

The few papers on calendar anomalies in the Ukrainian stock market include Hourvouliades and Kourkoumelis (2009), Depenchuk et al. (2010) and Caporale et al. (2016a,b), but these only focus on some specific anomalies (e.g., the Weekend Effect). The present one is the first comprehensive study of calendar anomalies in Ukraine.

\section{Data and Methodology}

We use daily and monthly data on the UX, PFTS and UX futures indices. The sample covers the period from November 2001 to the end of December 2015 for the PFTS Index, from January 2008 to the end of December 2015 for the UX Index, and from April 2010 to the end of December 2015 for the UX futures index. The data sources are the Ukrainian Exchange (http://www.ux.ua/en/) and PFTS Stock Exchange (http://www.pfts.ua/).

To examine whether there is a calendar effect we use the following techniques:

- $\quad$ average analysis

- $\quad$ parametric tests (Student's t-tests, ANOVA)

- $\quad$ non-parametric tests (Kruskal-Wallis test)

- $\quad$ regression analysis with dummy variables

Returns are computed as follows:

$$
\mathrm{R}_{\mathrm{i}}=\left(\frac{\operatorname{Close}_{\mathrm{i}}}{\operatorname{Close}_{\mathrm{i}-1}}-1\right) \times 100 \%,
$$

where $R_{i} \quad-\quad$ returns on the $i$-th day in \%; 


$$
\begin{aligned}
& \text { Open }_{i}-\quad \text { open price on the } i \text {-th day; } \\
& \text { Close }_{i}-\quad \text { close price on the } i \text {-th day. }
\end{aligned}
$$

Average analysis provides preliminary evidence on whether there are differences between returns in "normal” and "abnormal” periods. Both parametric and non-parametric tests are carried out given the evidence of fat tails and kurtosis in stock returns. The Null Hypothesis (H0) in each case is that the data belong to the same population, a rejection of the null suggesting the presence of an anomaly.

We use two variants of the Student's t, ANOVA and Kruskal-Wallis tests:

- overall testing - when all data are analysed together;

- separate testing - when we compare data from the period that might be characterised by an anomaly with those from other periods.

We also run multiple regressions including a dummy variable to identify given calendar anomalies:

$$
Y_{t}=a_{0}+a_{1} D_{1 t}+a_{2} D_{2 t}+\cdots+b_{n} D n_{t}+\varepsilon_{t}
$$

where $Y_{t}$ - return on the period $t$;

$a_{n}-$ mean return for a specific data group (for example Mondays, Tuesdays etc. in the case of the day of the week anomaly);

$\mathrm{D}_{\mathrm{nt}}$ - a dummy variable for a specific data group, equal to 1 when the data belong to a specific group (for example, data for a specific day of the week such as Monday in the case of the day of the week anomaly), and equal to 0 when they do not

$\varepsilon_{\mathrm{t}}-$ Random error term for period $t$.

The size, sign and statistical significance of the dummy coefficients provide information about possible anomalies.

When calendar anomalies are detected using the previous methods we examine whether these give rise to exploitable profit opportunities by means of a trading simulation approach. Specifically, we use an algorithm based on the detected anomaly to replicate the 
behaviour of a trader who opens positions on the Ukrainian stock market and holds them for a certain period of time (according to the developed algorithm).

We use the following procedure to simulate the trading process. First we compute the percentage result of the deal:

$$
\% \text { result }=\frac{100 \% \times P_{\text {open }}}{P_{\text {close }}}
$$

where $P_{\text {open }}$ - opening price

$$
P_{\text {close }} \text { - closing price }
$$

Then this difference is converted into Ukrainian hryvnas (UAH).

$$
\text { UAHresult }=\% \text { result } \times 1000
$$

where UAHresult - is result of the deal in UAH.

1000 is the sum of the trading deposit.

The sum of results from each deal in UAH is the total financial result of trading. A strategy resulting in a number of profitable trades $>50 \%$ and positive total profits is defined as indicating an exploitable market anomaly.

To make sure that the results we obtain are statistically different from the random trading ones we carry out t-tests. We chose this approach instead of carrying out z-tests because the sample size is less than 100. A t-test compares the means from two samples to see whether they come from the same population. In our case the first is the average profit/loss factor of one trade applying the trading strategy, and the second is equal to zero because random trading (without transaction costs) should generate zero profit.

The null hypothesis (H0) is that the mean is the same in both samples, and the alternative (H1) that it is not. The computed values of the t-test are compared with the critical one at the $5 \%$ significance level. Failure to reject $\mathrm{H} 0$ implies that there are no advantages from exploiting the trading strategy being considered, whilst a rejection suggests that the adopted strategy can generate abnormal profits. 


\section{Empirical Results}

The complete set of results can be found in Appendix B. Starting with the Day of the Week Effect, one can see (Figures B.1, B.2 and B.3) that there are no clear signs of this anomaly in the dynamics of the PFTS, UX and UX futures indices, as suggested by all statistical tests as well as the regression analysis. The results for the Turn of the Month Effect are reported in Appendix C. Visual inspection (Figures C.1, C.2 and C.3) suggests possible anomalies in the dynamics of the PFTS and UX but not of the UX futures index. However, this is only implied by the regression analysis, not by the other statistical tests. Although the PFTS index at the turn of the month is four times higher than on other days, this difference is not statistically significant.

The empirical results for the Turn of the Year Effect are presented in Appendix D.

Figures D.1, D.2 and D.3 provide visual evidence supporting the presence of this effect in the Ukrainian stock market, but this is confirmed only by the statistical tests for the PFTS index. As for the Month of the Year Effect (see Appendix E), visual inspection (Figures E.1, E.2 and E.3) does not suggest any anomalies, whilst the statistical tests provide some evidence for them in the case of the UX futures index: returns appear to be higher in February and lower in July-August in comparison to other months of the year. There is no evidence either of the Month of the Year Effect, or of the Holiday Effect (Appendix F): although visual inspection (Figures F.1, F.2 and F.3) suggests that pre-holidays returns are higher than normal and post-holiday ones (for both the PFTS and UX indices), these findings are not confirmed by either the statistical tests or the regression analysis.

Finally, concerning the Halloween Effect (see Appendix G), average analysis provides evidence in favour of the rule "sell in May and go away" since returns during the period November-April are much higher than in May-October (almost 7 times), but the statistical tests and the regression analysis show that this difference is significant only in the case of the PFST index. 
Table 1, 2 and 3 below summarise the results.

Table 1: Overall results for PFTS index

\begin{tabular}{|l|c|c|c|c|c|}
\hline Anomaly/Methodology & $\begin{array}{l}\text { Average } \\
\text { analysis }\end{array}$ & $\begin{array}{l}\text { Student's } \\
\text { t-test }\end{array}$ & ANOVA & $\begin{array}{l}\text { Kruskal - } \\
\text { Wallis } \\
\text { test }\end{array}$ & $\begin{array}{l}\text { Regression } \\
\text { analysis with } \\
\text { dummies }\end{array}$ \\
\hline Day of the Week Effect & - & - & - & - & - \\
\hline Turn of the Month Effect & + & - & - & - & + \\
\hline Turn of the Year Effect & + & + & + & + & + \\
\hline Month of the Year Effect & - & - & - & + & - \\
\hline Holiday Effect & + & - & - & - & - \\
\hline Halloween Effect & + & + & + & -- & + \\
\hline
\end{tabular}

Table 2: Overall results for UX index

\begin{tabular}{|l|c|c|c|c|c|}
\hline Anomaly/Methodology & $\begin{array}{l}\text { Average } \\
\text { analysis }\end{array}$ & $\begin{array}{l}\text { Student's } \\
\text { t-test }\end{array}$ & ANOVA & $\begin{array}{l}\text { Kruskal - } \\
\text { Wallis } \\
\text { test }\end{array}$ & $\begin{array}{l}\text { Regression } \\
\text { analysis with } \\
\text { dummies }\end{array}$ \\
\hline Day of the Week Effect & - & - & - & - & - \\
\hline Turn of the Month Effect & + & - & - & - & - \\
\hline Turn of the Year Effect & + & - & - & - & - \\
\hline Month of the Year Effect & - & + & - & - & - \\
\hline Holiday Effect & + & - & - & - & - \\
\hline Halloween Effect & + & - & - & - & - \\
\hline
\end{tabular}

Table 3: Overall results for UX futures

\begin{tabular}{|l|c|c|c|c|c|}
\hline Anomaly/Methodology & $\begin{array}{l}\text { Average } \\
\text { analysis }\end{array}$ & $\begin{array}{l}\text { Student's } \\
\text { t-test }\end{array}$ & ANOVA & $\begin{array}{l}\text { Kruskal - } \\
\text { Wallis } \\
\text { test }\end{array}$ & $\begin{array}{l}\text { Regression } \\
\text { analysis with } \\
\text { dummies }\end{array}$ \\
\hline Day of the Week Effect & - & - & - & - & - \\
\hline Turn of the Month Effect & - & - & - & - & - \\
\hline Turn of the Year Effect & + & - & - & - & - \\
\hline Month of the Year Effect & - & + & + & + & + \\
\hline Holiday Effect & - & - & - & - & - \\
\hline Halloween Effect & + & - & - & - & - \\
\hline
\end{tabular}

As can be seen, the only detected anomalies are the Turn of the Year and the Halloween Effect for the PFTS index, and the Month of the Year Effect for the UX futures index.

Next we use a trading simulation approach to answer the question whether these are simply statistical anomalies or instead represent exploitable profit opportunities. We begin with the Month of the Year Effect for the UX futures index. First we try to design 
appropriate trading rules, i.e. in which months long and short positions respectively should be opened.

Table 4: Anomalies by month for the UX futures

\begin{tabular}{|l|c|c|c|c|c|c|}
\hline Month & $\begin{array}{c}\text { Average } \\
\text { analysis }\end{array}$ & t-test & ANOVA & $\begin{array}{l}\text { Kruskal - } \\
\text { Wallis test }\end{array}$ & $\begin{array}{l}\text { Regression } \\
\text { analysis }\end{array}$ & Overall \\
\hline January & - & - & - & - & - & 0 \\
\hline February & + & + & + & + & - & 4 \\
\hline March & + & + & - & - & - & 2 \\
\hline April & - & - & - & - & - & 0 \\
\hline May & + & - & - & - & - & 1 \\
\hline June & - & - & - & - & - & 0 \\
\hline July & + & + & + & - & - & 3 \\
\hline August & + & + & - & + & - & 3 \\
\hline September & - & - & - & - & - & 0 \\
\hline October & - & - & - & - & - & 0 \\
\hline November & - & - & - & - & - & 0 \\
\hline December & + & - & - & - & - & 1 \\
\hline
\end{tabular}

As can be seen, in the case of UX futures anomalies are present mainly in February, July and August, therefore the trading strategy will be the following: open long positions in February and July (since returns on UX futures tend to be higher during these months) and short positions in August. All of them should be closed at the end of the period when they were opened. The trading simulation produces the following results:

Table 5: Trading simulation results for the Month of the Year Effect (UX futures)

\begin{tabular}{|l|c|c|c|c|c|c|}
\hline & $\begin{array}{c}\text { Number } \\
\text { of trades }\end{array}$ & $\begin{array}{c}\text { Number of } \\
\text { successful } \\
\text { trades }\end{array}$ & $\begin{array}{c}\% \text { of } \\
\text { successful } \\
\text { trades }\end{array}$ & $\begin{array}{c}\text { Financial } \\
\text { result, } \\
\text { UAH }\end{array}$ & $\begin{array}{c}\text { Overall } \\
\text { financial } \\
\text { result, \% }\end{array}$ & $\begin{array}{c}\text { Average } \\
\text { annual } \\
\text { financial } \\
\text { result, \% }\end{array}$ \\
\hline UX Futures & 17 & 14 & $82 \%$ & 2108 & $210 \%$ & $22 \%$ \\
\hline
\end{tabular}




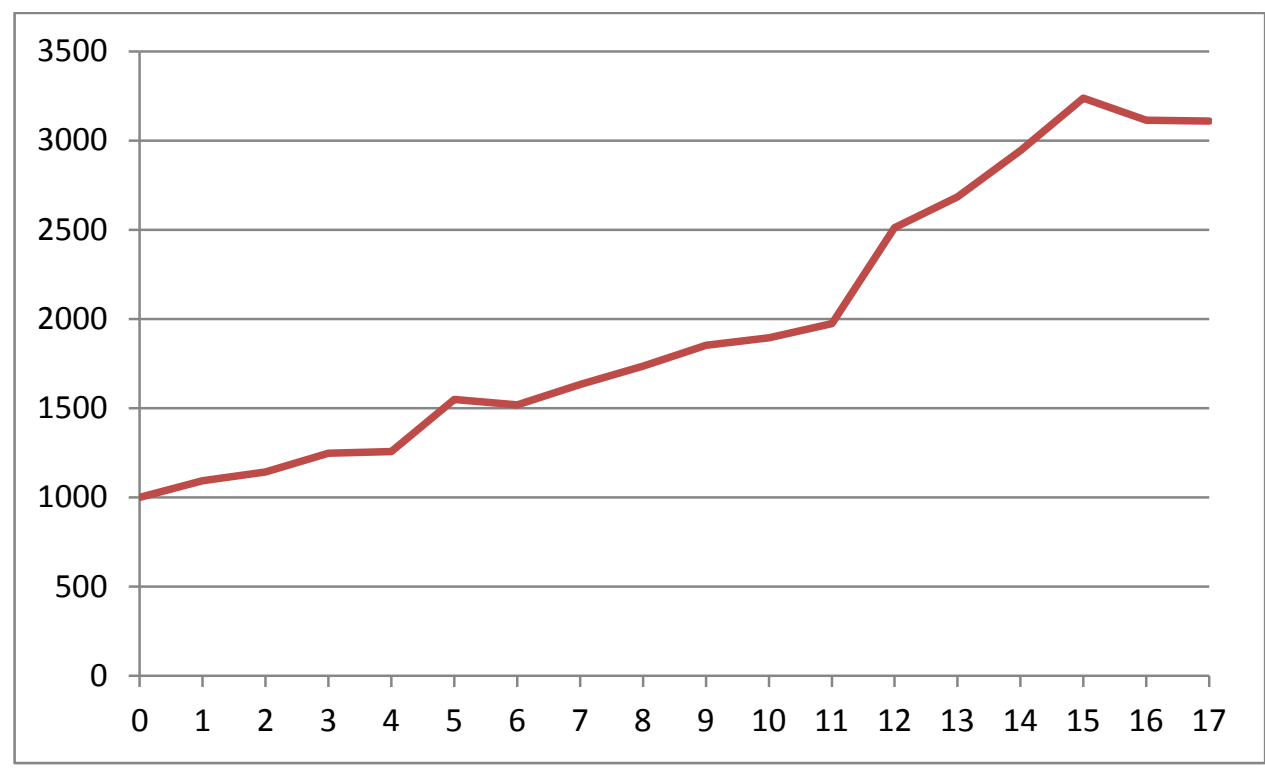

Figure 1 - Trading deposit dynamics for the trading strategy based on the Month of the Year Effect (UX futures)

The t-test results are reported in Table 6.

Table 6: T-test for the trading simulation results for the Month of the Year Effect (UX futures)

\begin{tabular}{|l|c|}
\hline \multicolumn{1}{|c|}{ Parameter } & Value \\
\hline Number of the trades & 17 \\
\hline Total profit (UAH) & 2108 \\
\hline Average profit per trade (UAH) & 124 \\
\hline Standard deviation (UAH) & 149 \\
\hline t-test & 3.42 \\
\hline t critical (0,95) & 2,11 \\
\hline Null hypothesis & rejected \\
\hline
\end{tabular}

As we can be seen, $\mathrm{H} 0$ is rejected, which implies that the trading simulation results for the Month of the Year Effect (in the case of UX futures) are statistically different from the random ones and therefore this trading strategy is effective and there is an exploitable profit opportunity.

Concerning the Turn of the Year effect for the PFTS index (stock returns in the last week of December and the first two weeks of January are higher than at other times of the year) the trading strategy will be the following: open a long position in the last week of 
December and close it after the first two weeks of January. The trading simulation yields the following results (see Table 7)

Table 7: Trading simulation results for the Turn of the Year Effect (PFTS index)

\begin{tabular}{|l|c|c|c|c|c|c|}
\hline Instrument & $\begin{array}{c}\text { Number } \\
\text { of trades }\end{array}$ & $\begin{array}{c}\text { Number of } \\
\text { successful } \\
\text { trades }\end{array}$ & $\begin{array}{c}\% \text { of } \\
\text { successful } \\
\text { trades }\end{array}$ & $\begin{array}{c}\text { Financial } \\
\text { result, } \\
\text { UAH }\end{array}$ & $\begin{array}{c}\text { Overall } \\
\text { financial } \\
\text { result, \% }\end{array}$ & $\begin{array}{c}\text { Average } \\
\text { annual } \\
\text { financial } \\
\text { result, \% }\end{array}$ \\
\hline UX Futures & 14 & 12 & $86 \%$ & 1093 & $100 \%$ & $5.7 \%$ \\
\hline
\end{tabular}

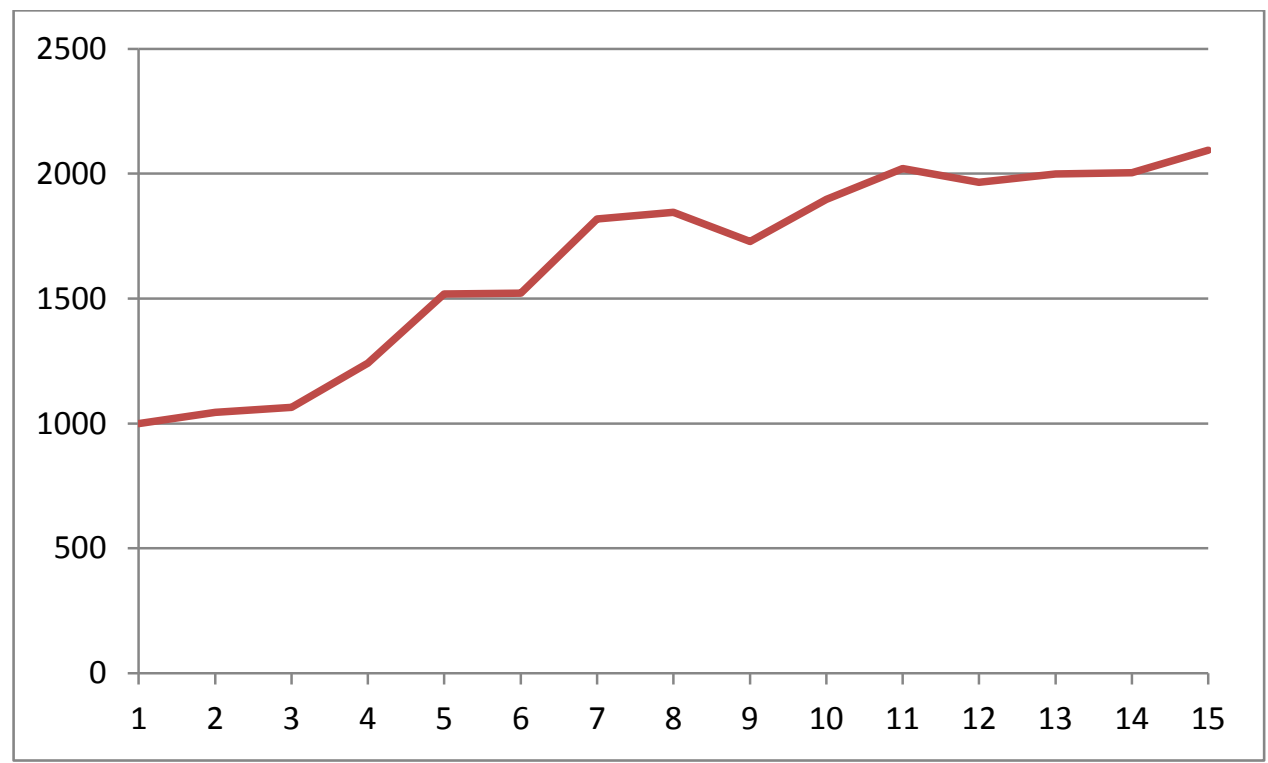

Figure 2 - Trading deposit dynamics for the trading strategy based on the Turn of the Year Effect (PFTS index)

The t-test results are reported in Table 8.

Table 8: T-test for the trading simulation results for the Turn of the Year Effect (PFTS index)

\begin{tabular}{|l|c|}
\hline \multicolumn{1}{|c|}{ Parameter } & Value \\
\hline Number of the trades & 14 \\
\hline Total profit (UAH) & 1093 \\
\hline Average profit per trade (UAH) & 78 \\
\hline Standard deviation (UAH) & 114 \\
\hline t-test & 2.55 \\
\hline t critical (0,95) & 2,14 \\
\hline Null hypothesis & rejected \\
\hline
\end{tabular}


In this case $\mathrm{H} 0$ is rejected, which again implies that the trading simulation results are statistically different from the random ones and therefore this trading strategy is also effective and can be exploited to make abnormal profits.

Finally, we focus on the Halloween Effect for the PFTS index. This investment strategy can be specified as "Sell in May and go away", i.e. stocks are sold at the beginning of May and bought again in the autumn. But since the regression analysis results indicated that in the case of the Ukrainian stock market only buys in the autumn generate abnormal returns, the trading strategy will be open long positions on the PFTS index in November and close them in May. The trading simulation results are the following (see Table 9):

Table 9: Trading simulation results for the Halloween Effect (PFTS index)

\begin{tabular}{|l|c|c|c|c|c|c|}
\hline Instrument & $\begin{array}{c}\text { Number } \\
\text { of trades }\end{array}$ & $\begin{array}{c}\text { Number of } \\
\text { successful } \\
\text { trades }\end{array}$ & $\begin{array}{c}\text { \% of } \\
\text { successful } \\
\text { trades }\end{array}$ & $\begin{array}{c}\text { Financial } \\
\text { result, } \\
\text { UAH }\end{array}$ & $\begin{array}{c}\text { Overall } \\
\text { financial } \\
\text { result, \% }\end{array}$ & $\begin{array}{c}\text { Average } \\
\text { annual } \\
\text { financial } \\
\text { result, \% }\end{array}$ \\
\hline UX Futures & 14 & 5 & $64 \%$ & 30358 & $3035 \%$ & $34 \%$ \\
\hline
\end{tabular}

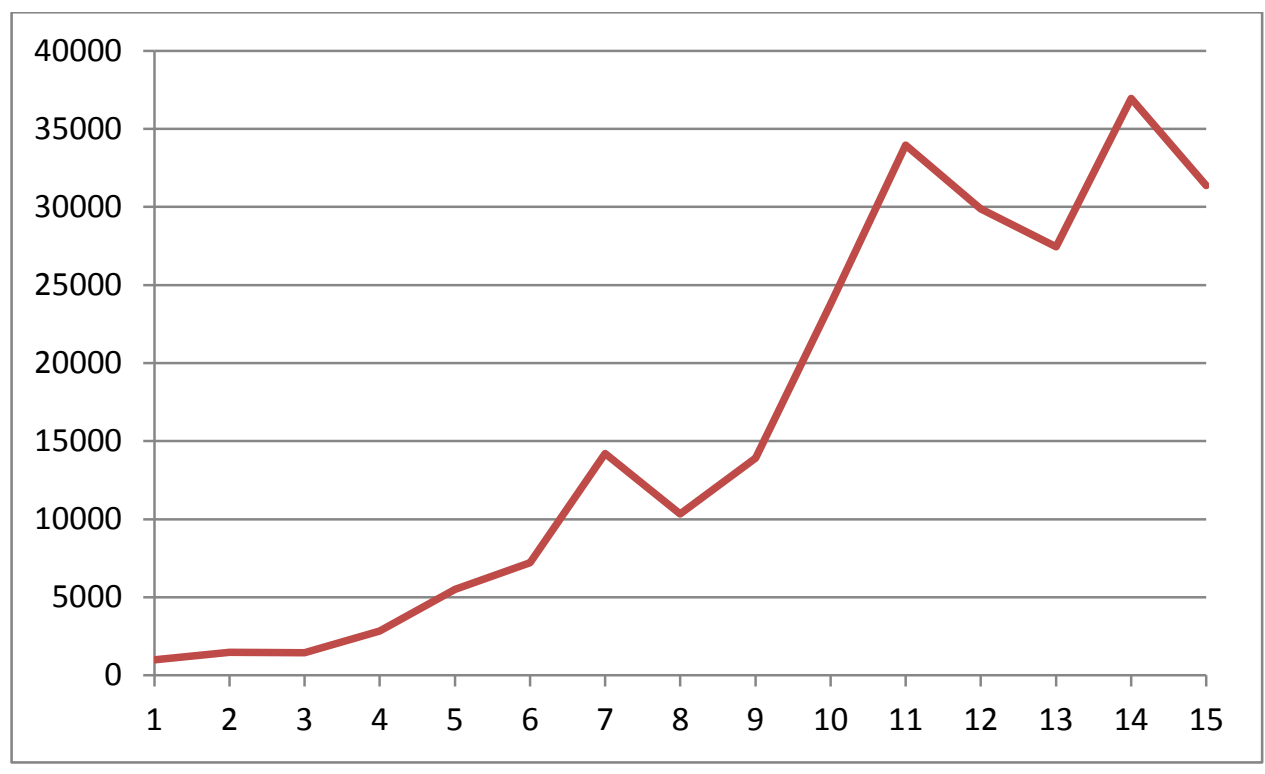

Figure 3 - Trading deposit dynamics for the trading strategy based on the Halloween Effect (PFTS index)

The t-test results are reported in Table 8. 
Table 10: T-test for the trading simulation results for the Halloween Effect (PFTS index)

\begin{tabular}{|l|c|}
\hline \multicolumn{1}{|c|}{ Parameter } & Value \\
\hline Number of the trades & 14 \\
\hline Total profit (UAH) & 30358 \\
\hline Average profit per trade (UAH) & 2168 \\
\hline Standard deviation (UAH) & 5127 \\
\hline t-test & 1.58 \\
\hline t critical (0,95) & 2,14 \\
\hline Null hypothesis & accepted \\
\hline
\end{tabular}

H0 now cannot be rejected, i.e. in this case there is no statistically significant difference between the trading simulation results and the random ones and therefore no exploitable profit opportunities.

\section{Conclusions}

In this paper we have examined calendar anomalies (Day of the Week Effect; Turn of the Month Effect; Turn of the Year Effect; Month of the Year Effect; January Effect; Holiday Effect; Halloween Effect) in the Ukrainian stock market using different methods (average analysis, parametric tests including Student's t-test and ANOVA, non-parametric tests such as the Kruskal-Wallis test and regression analysis with dummy variables). Three different indices (PFTS, UX and UX futures) have been considered to avoid data mining.

The results suggest that in general calendar anomalies are not present in the Ukrainian stock market, but there are a few exceptions, i.e. the Turn of the Year and Halloween Effect for the PFTS index, and the Month of the Year Effect for UX futures. However, the trading simulation analysis shows that only trading strategies based on the Turn of the Year Effect for the PFTS index and the Month of the Year Effect for the UX futures can generate exploitable profit opportunities that can be interpreted as evidence against market efficiency. 


\section{References}

Abhijeet, C., 2011, Stock Market Anomalies: A Test of Calendar Effect in the Bombay Stock Exchange (BSE). Indian Journal of Finance, 5 (5), 23-31.

Huson, A. and Z. Haque, 2009, The Day of the Week, Turn of the Month and January Effect on Stock Market Volatility and Volume: Evidence from Bursa Malaysia. Available at SSRN: http://ssrn.com/abstract=1460374.

Alshimmiri, T., 2011, Calendar Anomalies In Kuwait Stock Exchange: Anomalous Evidence. Journal of Business \& Economics Research, l (2), 37-50.

Ariel, R., 1987, A Monthly Effect in Stock Returns. The Journal of Financial Economics, $18,161-174$.

Ariel, R. 1990, High Stock Returns before Holidays: Existence and Evidence on Possible Causes. The Journal of Finance, 45, 1611-1626.

Barone, E., 1990, The Italian stock market: Efficiency and calendar anomalies. Journal of Banking and Finance, 14 (2-3), 483-510.

Bildik, R., 2004, Are Calendar Anomalies Still Alive?: Evidence from Istanbul Stock Exchange. Available at SSRN: http://ssrn.com/abstract=598904.

Borowski, K., 2015, Analysis of Selected Seasonality Effects in Market of Rubber Future Contracts Quoted on Tokyo Commodity Exchange. International Journal of Economics and Finance, 7 (9), 16-30.

Caporale, G.M., Gil-Alana L.A., and A. Plastun (2016a), "The weekend effect: an exploitable anomaly in the Ukrainian stock market?”, forthcoming, Journal of Economic Studies.

Caporale, G.M., Gil-Alana L.A., Plastun, A. and I. Makarenko (2016b), "The weekend effect: a trading robot and fractional integration analysis", forthcoming, International Journal of Bonds and Derivatives.

Carchano, O. and A. Pardo Tornero, 2011, Calendar Anomalies in Stock Index Futures. Available at SSRN: http://ssrn.com/abstract=1958587.

Clark, R., and W. Ziemba, 1987, Playing the Turn-Of-The-Year Effect with Index Futures. The Operations Research, 35, 799-813.

Compton, W., R. Kunkel, and G. Kuhlemeyer, 2013, Calendar anomalies in Russian stocks and bonds. Managerial Finance, 39(12), 1138-1154.

Cross, F., 1973, The behavior of stock prices on Fridays and Mondays. Financial Analysts Journal, 29 (6), 67-69.

Depenchuk, I., S. Compton, and R. Kunkel, 2010, Ukrainian financial markets: an examination of calendar anomalies. Managerial Finance, 36 (6), 502-510. 
Fortune, P., 1998, Weekends can be rough: Revisiting the weekend effect in stock prices. Federal Reserve Bank of Boston. Working Paper No. 98-6.

Fortune, P., 1999, Are stock returns different over weekends? a jump diffusion analysis of the «weekend effect». New England Economic Review, September-October, 3-19.

Georgantopoulos, A., D. Kenourgios, and A. Tsamis, 2011, Calendar Anomalies in Emerging Balkan Equity Markets. International Economics and Finance Journal, 6 (1), 67-82.

Giovanis, E., 2008, Calendar Anomalies in Athens Exchange Stock Market - An Application of GARCH Models and the Neural Network Radial Basis Function. Available at SSRN: http://ssrn.com/abstract=1264970.

Hansen, P., A. Lunde, and J. Nason, 2005, Testing the Significance of Calendar Effects. Federal Reserve Bank of Atlanta Working Paper No. 2005-02.

Hourvouliades, N., and N. Kourkoumelis, 2009, New Evidence for the Day-of-the-Week Effect in the Financial Crisis. International Conference on Applied Economics - ICOAE 2009, 225-243.

Jacobsen, B., and S. Bouman, 2002, The Halloween Indicator, 'Sell in May and Go Away': Another Puzzle. American Economic Review, 92 (5), 1618-1635.

Lakonishok, J., and S. Smidt, 1988, Are seasonal anomalies real? A Ninety-Year Perspective. The Review of Financial Studies, 1, 403-425.

Olson, D., N. Chou, and C. Mossman, 2010, Stages in the life of the weekend effect. Journal of Financial Economics, 21, 542-422.

Rozeff, M., and W. Kinney, 1976. Capital Market Seasonality: The Case of Stock Returns. Journal of Financial Economics, 3, 379-402

Schwert, G., 2003, Anomalies and market efficiency. Handbook of the Economics of Finance. Elsevier Science B.V., Ch.5, 937-972.

Lim, S., and R. Chia, 2009, Stock Market Calendar Anomalies: Evidence from ASEAN-5 Stock Markets. Economic Bulletin, 30 (2), 996-1005.

Silva, P., 2010, Calendar “anomalies” in the Portuguese stock market. Investment Analysts Journal, 39 (71), 37-50.

Stoica, O., and D. Diaconașu, 2011, An Examination of the Calendar Anomalies on Emerging Central and Eastern European Stock Markets. University of Iasi Working Paper. Recent Researches in Applied Economics, 11, 116-121.

Tangjitprom, N., 2011, The Calendar Anomalies of Stock Return in Thailand. Journal of Modern Accounting and Auditing, 7 (6), 565-577.

Wachtel, S., 2003, Certain observations on seasonal movements in stock prices, The Journal of Business of the University of Chicago, 15, 184-193.

Wong, W.-K., A. Agarwal, and N.-T. Wong, 2006, The Disappearing Calendar Anomalies in the Singapore Stock Market. The Lahore Journal of Economics, 11 (2), 123-139. 


\section{Appendix A}

Literature review

\begin{tabular}{|c|c|c|c|c|}
\hline Author & $\begin{array}{l}\text { Tested } \\
\text { effects }\end{array}$ & $\begin{array}{c}\text { Object of } \\
\text { analysis (time } \\
\text { period, market) }\end{array}$ & Methodology & Results \\
\hline $\begin{array}{l}\text { Lim and Chia } \\
\text { (2010) }\end{array}$ & $\begin{array}{l}\text { day of the } \\
\text { week effect } \\
\text { the twist of } \\
\text { the Monday } \\
\text { effect }\end{array}$ & $\begin{array}{l}\text { ASEAN }-5 \text { stock } \\
\text { markets for the } \\
\text { period June } 10 \text {, } \\
2002 \text { through } \\
\text { August } 21,2009\end{array}$ & $\begin{array}{l}\text { Kruskal -Wallis } \\
\text { statistic test }\end{array}$ & $\begin{array}{l}\text { Finds support for the day-of- } \\
\text { the -week effect in Malaysia } \\
\text { and Thailand stock markets. } \\
\text { Friday has the highest returns } \\
\text { in a week. Find evidence on } \\
\text { the twist of-the Monday } \\
\text { effect, where returns on } \\
\text { Mondays are influenced by } \\
\text { the previous week's returns. }\end{array}$ \\
\hline Giovanis (2008) & $\begin{array}{l}\text { day of the } \\
\text { week effect } \\
\text { the month of } \\
\text { the year } \\
\text { effect }\end{array}$ & $\begin{array}{l}\text { Athens Stock } \\
\text { Exchange } \\
\text { Market }\end{array}$ & $\begin{array}{l}\text { GARCH } \\
\text { estimation }\end{array}$ & $\begin{array}{l}\text { The Monday effect was } \\
\text { rejected for the Athens Stock } \\
\text { Market. The January effect } \\
\text { was found. }\end{array}$ \\
\hline $\begin{array}{l}\text { Georgantopoulos } \\
\text { et al. (2011) }\end{array}$ & $\begin{array}{l}\text { day of the } \\
\text { week effect, } \\
\text { the January } \\
\text { effect, the half } \\
\text { month effect, } \\
\text { the turn of the } \\
\text { month effect } \\
\text { the time of the } \\
\text { month effect }\end{array}$ & $\begin{array}{l}\text { emerging stock } \\
\text { markets } \\
\text { (Romania, } \\
\text { Bulgaria, } \\
\text { Croatia and } \\
\text { Turkey) and } \\
\text { Greece, during } \\
\text { the period 2000- } \\
2008\end{array}$ & $\begin{array}{l}\text { OLS } \\
\text { methodology on } \\
\text { appropriately } \\
\text { defined dummy } \\
\text { variables; } \\
\text { GARCH } \\
\text { estimation }\end{array}$ & $\begin{array}{l}\text { Provide evidence for the } \\
\text { existence of three calendar } \\
\text { effects (day of the week, turn } \\
\text { of the month, time of the } \\
\text { month) in both mean and } \\
\text { volatility equations for Greece } \\
\text { and Turkey }\end{array}$ \\
\hline Abhijeet (2011) & $\begin{array}{l}\text { turn of the } \\
\text { month effect } \\
\text { time of the } \\
\text { month effect }\end{array}$ & $\begin{array}{l}\text { Bombay Stock } \\
\text { Exchange (BSE) } \\
\text { for the period } \\
\text { April } 1998 \text { to } \\
\text { March } 2008\end{array}$ & $\begin{array}{l}\text { regression } \\
\text { equation with } \\
\text { dummy } \\
\text { variables }\end{array}$ & $\begin{array}{l}\text { For both the effects, the turn } \\
\text { of the month effect as well as } \\
\text { the time of the month effect, } \\
\text { significant values were found. }\end{array}$ \\
\hline $\begin{array}{l}\text { Huson and Haque } \\
\text { (2009) }\end{array}$ & $\begin{array}{l}\text { day of the } \\
\text { week, turn } \\
\text { of the month } \\
\text { January } \\
\text { effect }\end{array}$ & $\begin{array}{l}\text { Malaysian stock } \\
\text { index over the } \\
\text { period from } \\
1994 \text { to } 2004\end{array}$ & $\begin{array}{l}\text { GARCH (1 1)- } \\
\text { M model }\end{array}$ & $\begin{array}{l}\text { Findings indicate the } \\
\text { presence of a week-end } \\
\text { effect. No clear pattern of } \\
\text { January or turn of the month } \\
\text { effect was observed. }\end{array}$ \\
\hline $\begin{array}{l}\text { Tangjitprom } \\
\text { (2011) }\end{array}$ & $\begin{array}{l}\text { month-of- } \\
\text { year effect, } \\
\text { turn-of- } \\
\text { month } \\
\text { effect, } \\
\text { weekend } \\
\text { effect }\end{array}$ & $\begin{array}{l}\text { Thai stock } \\
\text { market. SET } \\
\text { index during } \\
1988 \text { to } 2009\end{array}$ & $\begin{array}{l}\text { multiple } \\
\text { regression } \\
\text { techniques } \\
\text { using dummy } \\
\text { variables }\end{array}$ & $\begin{array}{l}\text { Calendar anomalies exist in } \\
\text { Thai stock market. The return } \\
\text { is abnormally high during } \\
\text { December and January. } \\
\text { Return is abnormally high on } \\
\text { Fridays but abnormally low on } \\
\text { Mondays. }\end{array}$ \\
\hline $\begin{array}{l}\text { Compton et al } \\
\text { (2013) }\end{array}$ & $\begin{array}{l}\text { monthly } \\
\text { seasonality, } \\
\text { weekday } \\
\text { seasonality, }\end{array}$ & $\begin{array}{l}\text { two Russian } \\
\text { stock indices } \\
\text { and two } \\
\text { Russian bond }\end{array}$ & $\begin{array}{l}\text { multiple } \\
\text { regression } \\
\text { techniques } \\
\text { using dummy }\end{array}$ & $\begin{array}{l}\text { There is strong evidence of a } \\
\text { persistent monthly pattern } \\
\text { (but no January effect) and } \\
\text { strong evidence of weekday }\end{array}$ \\
\hline
\end{tabular}




\begin{tabular}{|c|c|c|c|c|}
\hline & $\begin{array}{l}\text { and a turn- } \\
\text { of-the- } \\
\text { month } \\
\text { seasonality }\end{array}$ & $\begin{array}{l}\text { indices during } \\
2000-2010\end{array}$ & variables & $\begin{array}{l}\text { seasonality (but no Monday } \\
\text { effect) in the Russian bond } \\
\text { market. There is also strong } \\
\text { support for a TOM effect in } \\
\text { the Russian and US stock } \\
\text { and bond markets. }\end{array}$ \\
\hline $\begin{array}{l}\text { Stoica and } \\
\text { Diaconașu (2011) }\end{array}$ & $\begin{array}{l}\text { day of the } \\
\text { week, } \\
\text { month of the } \\
\text { year effect }\end{array}$ & $\begin{array}{l}\text { Central Europe } \\
\text { stock markets } \\
\text { between } 2000 \\
\text { and } 2010\end{array}$ & $\begin{array}{l}\text { multiple } \\
\text { regression } \\
\text { techniques } \\
\text { using dummy } \\
\text { variables }\end{array}$ & $\begin{array}{l}\text { the Friday effect in Czech } \\
\text { Republic, Croatia and } \\
\text { Hungary, positive and } \\
\text { significant yields on Thursday } \\
\text { in the majority of the cases, } \\
\text { the existence of the month of } \\
\text { the year effect and the } \\
\text { existence of January effect in } \\
\text { Czech Republic, Croatia, } \\
\text { Macedonia, Romania, } \\
\text { Slovenia and Hungary. }\end{array}$ \\
\hline Bildik (2004) & $\begin{array}{l}\text { the day-of-the } \\
\text { week, turn-of- } \\
\text { the-year and } \\
\text { January, turn- } \\
\text { of-the-month, } \\
\text { intra-month, } \\
\text { and holiday } \\
\text { effects }\end{array}$ & $\begin{array}{l}\text { ISE-100 } \\
\text { (Turkish stock } \\
\text { market) index } \\
\text { from January } \\
2,1988, \text { to } \\
\text { January 15, } \\
1999\end{array}$ & $\begin{array}{l}\text { regressions } \\
\text { with dummy } \\
\text { variables }\end{array}$ & $\begin{array}{l}\text { results indicate that calendar } \\
\text { anomalies are still } \\
\text { significantly existed in the ISE } \\
\text { both in stock returns and } \\
\text { trading volume consistent to } \\
\text { international evidence. }\end{array}$ \\
\hline Alshimmiri (2011) & $\begin{array}{l}\text { January and } \\
\text { weekend } \\
\text { effects, } \\
\text { Halloween } \\
\text { Effect }\end{array}$ & $\begin{array}{l}\text { Kuwait Stock } \\
\text { Exchange Index } \\
\text { period } \\
1984-2000\end{array}$ & $\begin{array}{l}\text { regressions } \\
\text { with dummy } \\
\text { variables }\end{array}$ & $\begin{array}{l}\text { a weekend effect exists. } \\
\text { January effect is not } \\
\text { detected. returns during } \\
\text { summer months (May- } \\
\text { September) tend to be } \\
\text { significantly higher than } \\
\text { returns during other months } \\
\text { of the year (October-April) }\end{array}$ \\
\hline Silva (2010) & $\begin{array}{l}\text { The Turn-of- } \\
\text { the-month } \\
\text { and the } \\
\text { Holiday } \\
\text { effect } \\
\text { Weekday or } \\
\text { the January } \\
\text { "anomalies" }\end{array}$ & $\begin{array}{l}\text { PSI-Geral and } \\
\text { PSI20-TR, } \\
\text { period 1998- } \\
2008\end{array}$ & $\begin{array}{l}\text { standard OLS } \\
\text { regressions } \\
\text { with dummies } \\
\text { and tests for } \\
\text { the equality of } \\
\text { means (F-tests } \\
\text { and Kruskall- } \\
\text { Wallis test). T- } \\
\text { test and the } \\
\text { Mann-Whitney } \\
\text { test }\end{array}$ & $\begin{array}{l}\text { No Weekday or the January } \\
\text { "anomalies". The significant } \\
\text { "anomalies" were the Pre- } \\
\text { holiday effect (where average } \\
\text { returns are twelve times } \\
\text { higher the other days' } \\
\text { returns) and a Turn-of the- } \\
\text { month effect. }\end{array}$ \\
\hline Wong et al (2006) & $\begin{array}{l}\text { January } \\
\text { effect, the } \\
\text { day-of-the- } \\
\text { week effect, } \\
\text { the turn-of- } \\
\text { the-month } \\
\text { effect and } \\
\text { holiday effect }\end{array}$ & $\begin{array}{l}\text { Singapore stock } \\
\text { market over the } \\
\text { recent period } \\
\text { from 1993-2005 }\end{array}$ & $\begin{array}{l}\text { GARCH(1,1) } \\
\text { model; t-test } \\
\text { for two } \\
\text { independent } \\
\text { samples }\end{array}$ & $\begin{array}{l}\text { The findings reveal that these } \\
\text { anomalies have largely } \\
\text { disappeared from the } \\
\text { Singapore stock market in } \\
\text { recent years. }\end{array}$ \\
\hline
\end{tabular}




\begin{tabular}{|c|c|c|c|c|}
\hline Barone (1990) & $\begin{array}{l}\text { weekend and } \\
\text { holidays, the } \\
\text { end of the } \\
\text { months, and } \\
\text { the end of the } \\
\text { year }\end{array}$ & $\begin{array}{l}\text { Milan Stock } \\
\text { Exchange's } \\
\text { 'MIB storico' } \\
\text { stock index } \\
\text { period 1975- } \\
1989\end{array}$ & $\begin{array}{l}\text { regressions } \\
\text { with dummies, } \\
\text { average } \\
\text { analysis }\end{array}$ & $\begin{array}{l}\text { Find evidence of anomalous } \\
\text { changes, though not all are } \\
\text { stable over time. }\end{array}$ \\
\hline Borowski (2015) & $\begin{array}{l}\text { monthly, } \\
\text { daily, the } \\
\text { day-of-the } \\
\text { week, the } \\
\text { first and the } \\
\text { second half } \\
\text { of monthly } \\
\text { effects }\end{array}$ & $\begin{array}{l}\text { market of } \\
\text { rubber futures, } \\
\text { quoted in the } \\
\text { Tokyo } \\
\text { Commodity } \\
\text { Exchange } \\
\text { period from } \\
01.12 .1981 \text { to } \\
31.03 .2015\end{array}$ & ANOVA & $\begin{array}{l}\text { Calculations indicate the } \\
\text { existence of monthly effect. } \\
\text { The seasonal effects were } \\
\text { also observed for daily } \\
\text { averaged rates of returns for } \\
\text { different days of the month } \\
\text { (15th), as well as for the daily } \\
\text { average rates of return on } \\
\text { various days of the week } \\
\text { (Thursday). The seasonal } \\
\text { effects were no registered for } \\
\text { the daily average rates of } \\
\text { return in the first and in the } \\
\text { second half of a month. }\end{array}$ \\
\hline $\begin{array}{l}\text { Carchano and } \\
\text { Pardo Tornero } \\
\text { (2011) }\end{array}$ & $\begin{array}{l}\text { day-of-the- } \\
\text { week, month- } \\
\text { of-the-year, } \\
\text { weekday, } \\
\text { week-of-the- } \\
\text { month, semi- } \\
\text { month, turn- } \\
\text { of-the-month, } \\
\text { end-of-year, } \\
\text { holiday- } \\
\text { effects, semi- } \\
\text { month-of-the- } \\
\text { year, and } \\
\text { week-of-the- } \\
\text { month-of-the- } \\
\text { year }\end{array}$ & $\begin{array}{l}\text { S\&P 500, DAX } \\
\text { and Nikkei stock } \\
\text { index futures } \\
\text { contracts from } \\
1991 \text { to } 2008\end{array}$ & $\begin{array}{l}\text { percentile-t- } \\
\text { bootstrap and } \\
\text { Monte Carlo } \\
\text { methods }\end{array}$ & $\begin{array}{l}\text { the turn-of-the-month effect in } \\
\text { S\&P } 500 \text { futures contracts is } \\
\text { the only calendar effect that is } \\
\text { statistically and economically } \\
\text { significant and persistent over } \\
\text { time. }\end{array}$ \\
\hline $\begin{array}{l}\text { Hansen et al } \\
(2005)\end{array}$ & \begin{tabular}{|l|} 
day-of-the \\
week, turn-of- \\
the-year and \\
January, turn- \\
of-the-month, \\
intra-month, \\
holiday effects
\end{tabular} & $\begin{array}{|lr|}\text { stock indices from } \\
\text { Denmark, France, } \\
\text { Germany, Hong } \\
\text { Kong, Italy, Japan, } \\
\text { Norway, Sweden, } \\
\text { United Kingdom, } \\
\text { United States } \\
\text { period until } 2002\end{array}$ & $x^{2}$ test & $\begin{array}{l}\text { Calendar effects are } \\
\text { significant for returns in most } \\
\text { of these equity markets, but } \\
\text { end-of-the-year effects are } \\
\text { predominant. }\end{array}$ \\
\hline Caporale (2014) & $\begin{array}{l}\text { day-of-the } \\
\text { week }\end{array}$ & $\begin{array}{l}35 \text { US companies } \\
\text { included in the } \\
\text { Dow Jones index, } \\
8 \text { Blue-chip } \\
\text { Russian } \\
\text { companies, } \\
\text { period 2005-2014 }\end{array}$ & $\begin{array}{l}\text { A Trading } \\
\text { Robot and } \\
\text { Fractional } \\
\text { Integration } \\
\text { Analysis }\end{array}$ & $\begin{array}{l}\text { Anomaly cannot be exploited } \\
\text { to make abnormal profits, and } \\
\text { therefore it is not inconsistent } \\
\text { with the Efficient Market } \\
\text { Hypothesis }\end{array}$ \\
\hline
\end{tabular}




\section{Appendix B}

\section{Empirical results for the Day of the Week Effect}

\section{Average analysis}

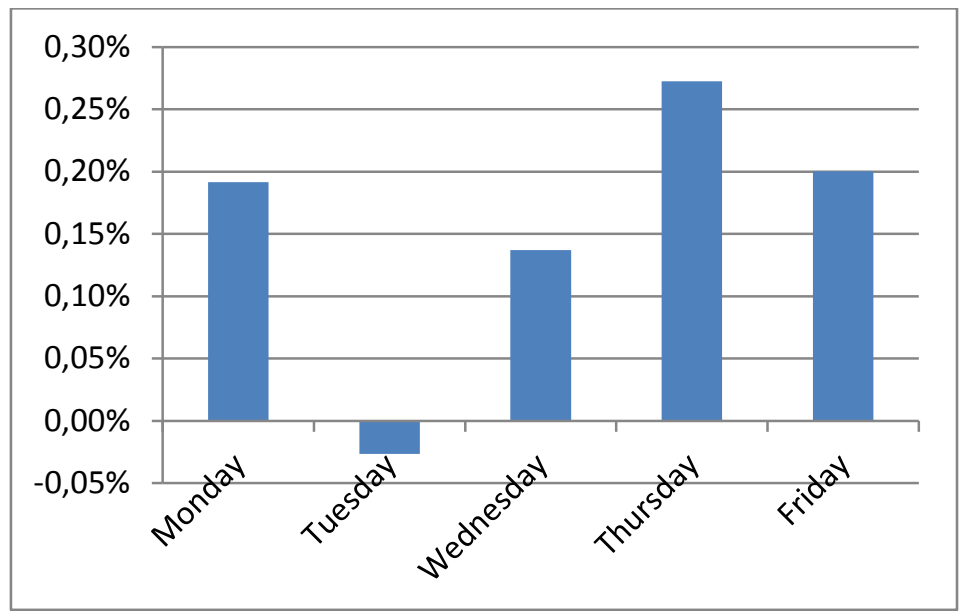

Figure B.1 - Average analysis case of PFTS index

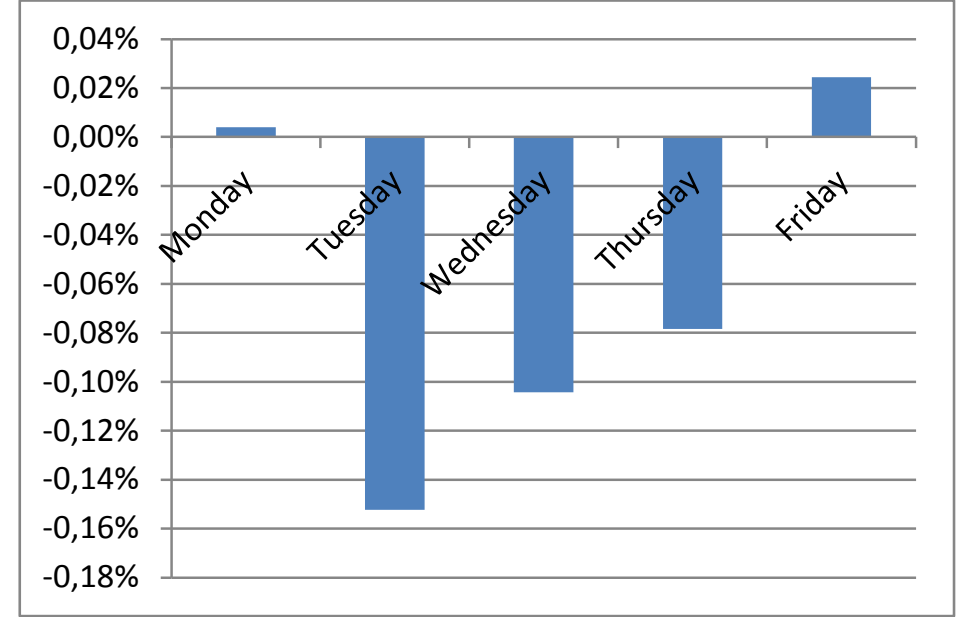

Figure B.2 - Average analysis case of UX index

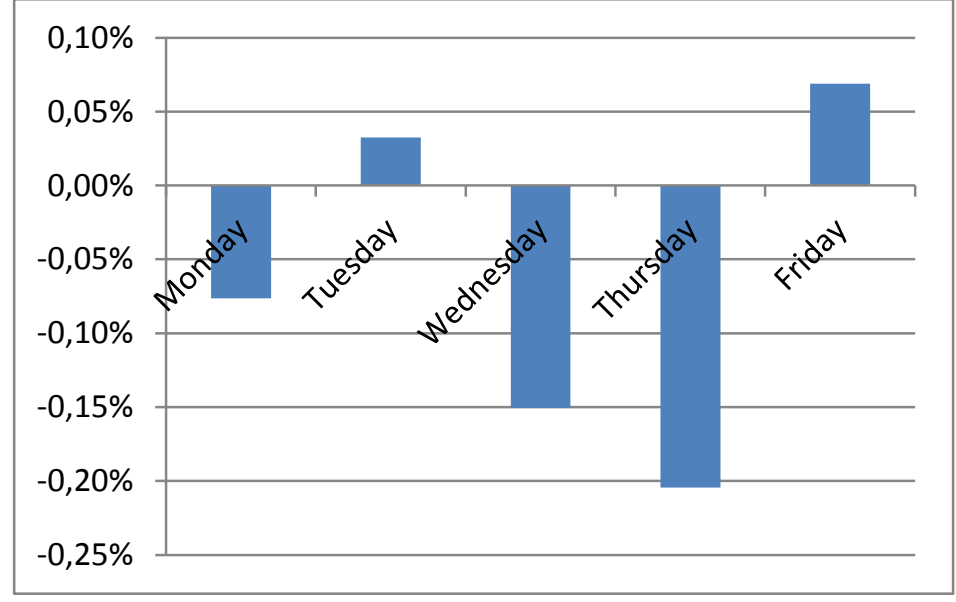

Figure B.3 - Average analysis case of UX futures 
Parametric tests: Student's t-test

Table B.1: T-test of the Day of the Week Effect for PFTS index

\begin{tabular}{|l|c|c|c|c|c|}
\hline \multicolumn{1}{|c|}{ Parameter } & Monday & Tuesday & Wednesday & Thursday & Friday \\
\hline \multicolumn{7}{|c|}{ Population 1 (data without day of analysis) } \\
\hline Mean,\% & $0,15 \%$ & $0,20 \%$ & $0,16 \%$ & $0,12 \%$ & $0,14 \%$ \\
\hline Standard deviation,\% & $2,13 \%$ & $2,11 \%$ & $2,16 \%$ & $2,16 \%$ & $2,15 \%$ \\
\hline Number of observations & 1623 & 1582 & 1579 & 1580 & 1588 \\
\hline \multicolumn{7}{|c|}{ Population 2 (data for the day of analysis) } \\
\hline Mean,\% & $0,19 \%$ & $-0,03 \%$ & $0,14 \%$ & $0,27 \%$ & $0,20 \%$ \\
\hline Standard deviation,\% & $2,21 \%$ & $2,25 \%$ & $2,06 \%$ & $2,09 \%$ & $2,12 \%$ \\
\hline Number of observations & 365 & 406 & 409 & 408 & 400 \\
\hline \multicolumn{7}{|c|}{ T-test results } \\
\hline t-criterion & 0,36 & $-1,84$ & $-0,19$ & 1,27 & 0,49 \\
\hline t-critical (p=0,95) & Accepted & Accepted & Accepted & Accepted & Accepted \\
\hline Null hypothesis
\end{tabular}

Table B.2: T-test of the Day of the Week Effect for UX index

\begin{tabular}{|l|c|c|c|c|c|}
\hline \multicolumn{1}{|c|}{ Parameter } & Monday & Tuesday & Wednesday & Thursday & Friday \\
\hline \multicolumn{7}{|c|}{ Population 1 (data without day of analysis) } \\
\hline Mean,\% & $-0,08 \%$ & $-0,04 \%$ & $-0,05 \%$ & $-0,06 \%$ & $-0,08 \%$ \\
\hline Standard deviation,\% & $2,43 \%$ & $2,45 \%$ & $2,56 \%$ & $2,54 \%$ & $2,60 \%$ \\
\hline Number of observations & 1145 & 1118 & 1115 & 1118 & 1124 \\
\hline \multicolumn{7}{|c|}{ Population 2 (data for the day of analysis) } \\
\hline Mean,\% & $0,00 \%$ & $-0,15 \%$ & $-0,10 \%$ & $-0,08 \%$ & $0,02 \%$ \\
\hline Standard deviation,\% & $2,86 \%$ & $2,77 \%$ & $2,33 \%$ & $2,43 \%$ & $2,15 \%$ \\
\hline Number of observations & 260 & 287 & 290 & 287 & 281 \\
\hline \multicolumn{7}{|c|}{ T-test results } \\
\hline t-criterion & 0,43 & $-0,63$ & $-0,34$ & $-0,13$ & 0,71 \\
\hline t-critical (p=0,95) & Accepted & Accepted & Accepted & Accepted & Accepted \\
\hline Null hypothesis
\end{tabular}

Table B.3: T-test of the Day of the Week Effect for UX index futures

\begin{tabular}{|l|c|c|c|c|c|}
\hline \multicolumn{1}{|c|}{ Parameter } & Monday & Tuesday & Wednesday & Thursday & Friday \\
\hline \multicolumn{7}{|c|}{ Population 1 (data without day of analysis) } \\
\hline Mean,\% & $-0,06 \%$ & $-0,09 \%$ & $-0,04 \%$ & $-0,03 \%$ & $-0,10 \%$ \\
\hline Standard deviation,\% & $2,08 \%$ & $2,20 \%$ & $2,29 \%$ & $2,34 \%$ & $2,32 \%$ \\
\hline Number of observations & 1145 & 1118 & 1115 & 1118 & 1124 \\
\hline \multicolumn{7}{|c|}{ Population 2 (data for the day of analysis) } \\
\hline Mean,\% & $-0,08 \%$ & $0,03 \%$ & $-0,15 \%$ & $-0,20 \%$ & $0,07 \%$ \\
\hline Standard deviation,\% & $2,88 \%$ & $2,42 \%$ & $2,05 \%$ & $1,85 \%$ & $1,94 \%$ \\
\hline Number of observations & 260 & 287 & 290 & 287 & 281 \\
\hline \multicolumn{7}{|c|}{ T-test results } \\
\hline t-criterion & $-0,06$ & 0,79 & $-0,76$ & $-1,34$ & 1,26 \\
\hline t-critical (p=0,95) & Accepted & Accepted & Accepted & Accepted & Accepted \\
\hline Null hypothesis
\end{tabular}




\section{Parametric tests: ANOVA}

Table B.4: ANOVA test of the Day of the Week Effect for PFTS index

\begin{tabular}{|l|c|c|c|c|}
\hline & $\mathrm{F}$ & $\mathrm{p}$-value & F critical & Null hypothesis \\
\hline Overall & 1,04 & 0,39 & 2,38 & Accepted \\
\hline Monday & 0,60 & 0,44 & 3,85 & Accepted \\
\hline Tuesday & 3,84 & 0,05 & 3,85 & Accepted \\
\hline Wednesday & 0,07 & 0,80 & 3,85 & Accepted \\
\hline Thursday & 0,45 & 0,50 & 3,85 & Accepted \\
\hline Friday & 0,09 & 0,77 & 3,85 & Accepted \\
\hline
\end{tabular}

Table B.5: ANOVA test of the Day of the Week Effect for UX index

\begin{tabular}{|l|c|c|c|c|}
\hline & $\mathrm{F}$ & $\mathrm{p}$-value & F critical & Null hypothesis \\
\hline Overall & 0,32 & 0,87 & 2,38 & Accepted \\
\hline Monday & 0,02 & 0,88 & 3,85 & Accepted \\
\hline Tuesday & 0,49 & 0,49 & 3,85 & Accepted \\
\hline Wednesday & 0,02 & 0,89 & 3,85 & Accepted \\
\hline Thursday & 0,04 & 0,84 & 3,85 & Accepted \\
\hline Friday & 1,04 & 0,31 & 3,85 & Accepted \\
\hline
\end{tabular}

Table B.6: ANOVA test of the Day of the Week Effect for UX futures

\begin{tabular}{|l|c|c|c|c|}
\hline & F & F critical & p-value & Null hypothesis \\
\hline Overall & 0,77 & 0,55 & 2,38 & Accepted \\
\hline Monday & 0,01 & 0,91 & 3,86 & Accepted \\
\hline Tuesday & 0,60 & 0,44 & 3,86 & Accepted \\
\hline Wednesday & 0,53 & 0,47 & 3,86 & Accepted \\
\hline Thursday & 1,62 & 0,20 & 3,86 & Accepted \\
\hline Friday & 1,45 & 0,23 & 3,86 & Accepted \\
\hline
\end{tabular}


Table B.7: Kruskal -Wallis test of the Day of the Week Effect for PFTS index

\begin{tabular}{|l|c|c|c|c|c|c|}
\hline Parameter & Overall & Monday & Tuesday & Wednesday & Thursday & Friday \\
\hline Adjusted H & 4,32 & 3,59 & 3,56 & 0,04 & 0,04 & 0,26 \\
\hline d.f. & 4 & 1 & 1 & 1 & 1 & 1 \\
\hline P value: & 0,36 & 0,06 & 0,06 & 0,84 & 0,84 & 0,61 \\
\hline Critical value & 9,48 & 3,84 & 3,84 & 3,84 & 3,84 & 3,84 \\
\hline Null hypothesis & Accepted & Accepted & Accepted & Accepted & Accepted & Accepted \\
\hline
\end{tabular}

Table B.8: Kruskal -Wallis test of the Day of the Week Effect for UX index

\begin{tabular}{|l|c|c|c|c|c|c|}
\hline Parameter & Overall & Monday & Tuesday & Wednesday & Thursday & Friday \\
\hline Adjusted H & 2,24 & 0,01 & 0,36 & 0,50 & 1,27 & 0,35 \\
\hline d.f. & 4 & 1 & 1 & 1 & 1 & 1 \\
\hline P value: & 0,69 & 0,94 & 0,55 & 0,48 & 0,26 & 0,55 \\
\hline Critical value & 9,48 & 3,84 & 3,84 & 3,84 & 3,84 & 3,84 \\
\hline Null hypothesis & Accepted & Accepted & Accepted & Accepted & Accepted & Accepted \\
\hline
\end{tabular}

Table B.9: Kruskal -Wallis test of the Day of the Week Effect for UX futures

\begin{tabular}{|l|c|c|c|c|c|c|}
\hline Parameter & Overall & Monday & Tuesday & Wednesday & Thursday & Friday \\
\hline Adjusted H & 4,54 & 0,02 & 0,01 & 0,17 & 1,74 & 0,78 \\
\hline d.f. & 4 & 1 & 1 & 1 & 1 & 1 \\
\hline P value: & 0,34 & 0,88 & 0,91 & 0,68 & 0,19 & 0,38 \\
\hline Critical value & 9,48 & 3,84 & 3,84 & 3,84 & 3,84 & 3,84 \\
\hline Null hypothesis & Accepted & Accepted & Accepted & Accepted & Accepted & Accepted \\
\hline
\end{tabular}

\section{Regression analysis with dummy variables}

Table B.10: Regression analysis with dummy variables of the Day of the Week Effect for PFTS index, UX index and UX index*

\begin{tabular}{|l|c|c|c|}
\hline \multicolumn{1}{|c|}{ Parameter } & PFTS index & UX index & UX futures \\
\hline Monday $\left(\mathrm{a}_{0}\right)$ & $0,0019(0.0869)$ & $-0,0002(0.8680)$ & $-0,0008(0.5870)$ \\
\hline Tuesday $\left(\mathrm{a}_{1}\right)$ & $-0,0022(0.1587)$ & $-0,0012(0.4700)$ & $0,0012(0.5331)$ \\
\hline Wednesday $\left(\mathrm{a}_{2}\right)$ & $-0,0004(0.7763)$ & $-0,0003(0.8612)$ & $0,0002(0.9048)$ \\
\hline Thursday $\left(\mathrm{a}_{3}\right)$ & $0,0007(0.6593)$ & $-0,0005(0.7478)$ & $-0,0007(0.7126)$ \\
\hline Friday $\left(\mathrm{a}_{4}\right)$ & $0,0001(0.9542)$ & $0,0006(0.7370)$ & $0,0029(0.1414)$ \\
\hline F-test & $1,04(0.3868)$ & $0,32(0.8653)$ & $1,01(0.4004)$ \\
\hline Multiple R & 0,05 & 0,03 & 0,06 \\
\hline Anomaly & Not confirmed & Not confirmed & Not confirmed \\
\hline
\end{tabular}

\footnotetext{
* P-values are in parentheses
} 


\section{Appendix C}

\section{Empirical results for the Turn of the Month Effect}

\section{Average analysis}

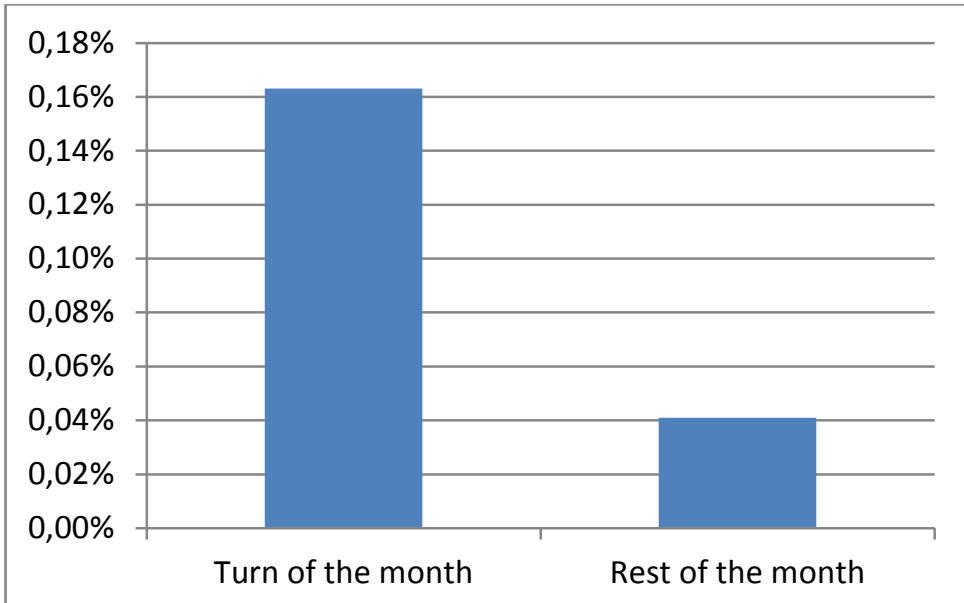

Figure C.1 - Average analysis case of PFTS index

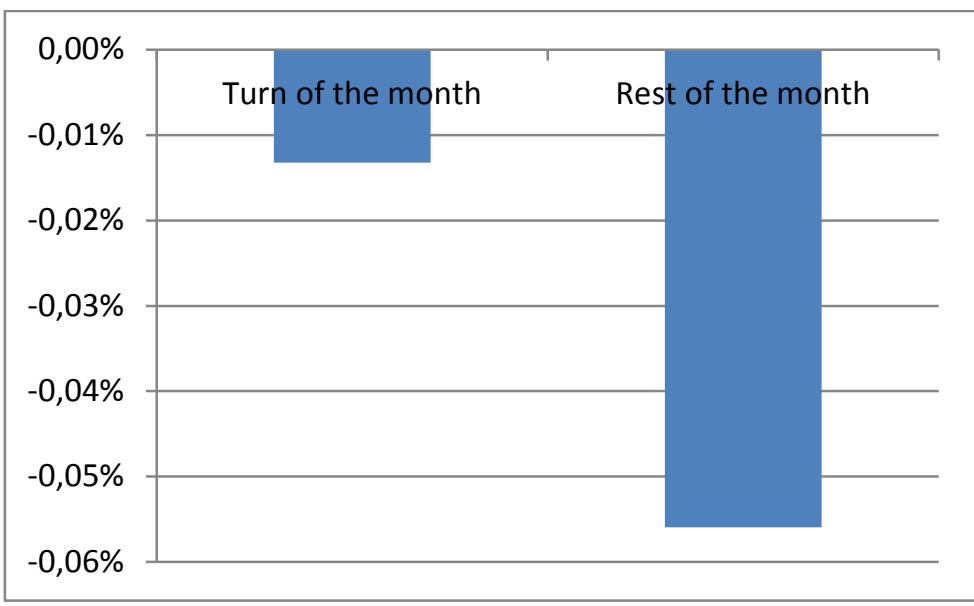

Figure C.2 - Average analysis case of UX index

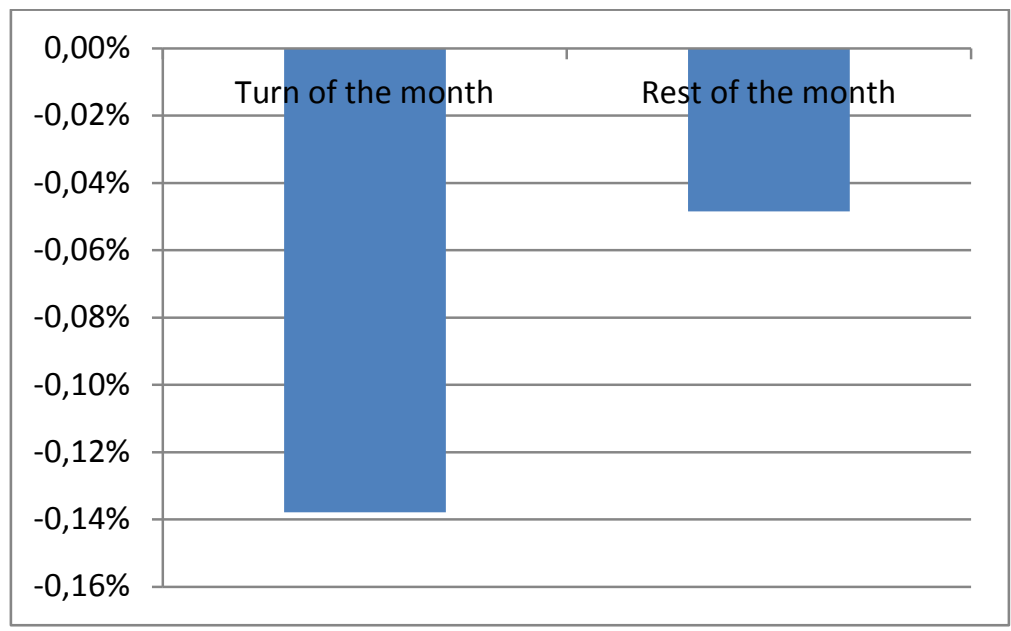

Figure C.3 - Average analysis case of UX futures 
Table C.1: T-test of the Turn of the Month Effect for PFTS index, UX index and UX futures

\begin{tabular}{|l|c|c|c|c|c|c|}
\hline \multirow{2}{*}{ Parameter } & \multicolumn{2}{|c|}{ PFTS index } & \multicolumn{2}{c|}{ UX index } & \multicolumn{2}{c|}{ UX futures } \\
\cline { 2 - 7 } & $\begin{array}{c}\text { Turn of the } \\
\text { month } \\
{[-1+3]}\end{array}$ & $\begin{array}{c}\text { Rest of the } \\
\text { month } \\
{[+4-2]}\end{array}$ & $\begin{array}{c}\text { Turn of } \\
\text { the month } \\
{[-1+3]}\end{array}$ & $\begin{array}{c}\text { Rest of } \\
\text { the month } \\
{[+4-2]}\end{array}$ & $\begin{array}{c}\text { Turn of } \\
\text { the month } \\
{[-1+3]}\end{array}$ & $\begin{array}{c}\text { Rest of } \\
\text { the month } \\
{[+4-2]}\end{array}$ \\
\hline Mean,\% & $0,16 \%$ & $0,04 \%$ & $-0,01 \%$ & $-0,06 \%$ & $-0,14 \%$ & $-0,05 \%$ \\
\hline Standard deviation,\% & $2,31 \%$ & $1,82 \%$ & $2,40 \%$ & $2,28 \%$ & $2,24 \%$ & $2,25 \%$ \\
\hline Number of observations & 680 & 2840 & 380 & 1610 & 270 & 1134 \\
\hline t-criterion & \multicolumn{2}{|c|}{1,29} & \multicolumn{2}{c|}{0,31} & \multicolumn{2}{c|}{0,59} \\
\hline t-critical $(p=0,95)$ & \multicolumn{2}{|c|}{1.96} & \multicolumn{2}{c|}{1.96} & \multicolumn{2}{c|}{1.96} \\
\hline Null hypothesis & \multicolumn{2}{|c|}{ Accepted } & \multicolumn{2}{c|}{ Accepted } & \multicolumn{2}{c|}{ Accepted } \\
\hline
\end{tabular}

Parametric tests: ANOVA

Table C.2: ANOVA test of the Turn of the Month Effect for PFTS index, UX index and UX index

\begin{tabular}{|l|c|c|c|c|}
\hline Instrument & $\mathrm{F}$ & $\mathrm{p}$-value & F critical & Null hypothesis \\
\hline PFTS index & 2,22 & 0,14 & 3,84 & Accepted \\
\hline UX index & 0,11 & 0,74 & 3,85 & Accepted \\
\hline UX futures & 0,35 & 0,56 & 3,85 & Accepted \\
\hline
\end{tabular}

Non-parametric tests: Kruskal -Wallis test

Table C.3: Kruskal -Wallis test of the Turn of the Month Effect for PFTS index, UX index and $U X$ index

\begin{tabular}{|l|c|c|c|c|c|}
\hline Instrument & $\begin{array}{c}\text { Adjusted } \\
\mathrm{H}\end{array}$ & d.f. & P value: & $\begin{array}{c}\text { Critical } \\
\text { value }\end{array}$ & Null hypothesis \\
\hline PFTS index & 0,06 & 1 & 0,81 & 3.84 & Accepted \\
\hline UX index & 0,02 & 1 & 0,89 & 3.84 & Accepted \\
\hline UX futures & 0,21 & 1 & 0,65 & 3.84 & Accepted \\
\hline
\end{tabular}

Regression analysis with dummy variables

Table C.4: Regression analysis with dummy variables of the Turn of the Month Effect for PFTS index, UX index and UX index*

\begin{tabular}{|l|c|c|c|}
\hline \multicolumn{1}{|c|}{ Parameter } & PFTS index & UX index & UX futures \\
\hline Turn of the Month $\left(\mathrm{a}_{0}\right)$ & $\mathbf{0 , 0 0 1 6 ( \mathbf { 0 . 0 3 } )}$ & $-0,0001(0.91)$ & $-0,0014(0.31)$ \\
\hline Rest of the Month $\left(\mathrm{a}_{1}\right)$ & $-0,0012(0.14)$ & $-0,0004(0.74)$ & $0,0009(0.56)$ \\
\hline F-test & $2,22(0.14)$ & $0,11(0.74)$ & $0,35(0.55)$ \\
\hline Multiple R & 0,03 & 0,01 & 0,02 \\
\hline Anomaly & Confirmed & Not confirmed & Not confirmed \\
\hline
\end{tabular}

* P-values are in parentheses 


\section{Appendix D}

\section{Empirical results for the Turn of the Year Effect}

\section{Average analysis}

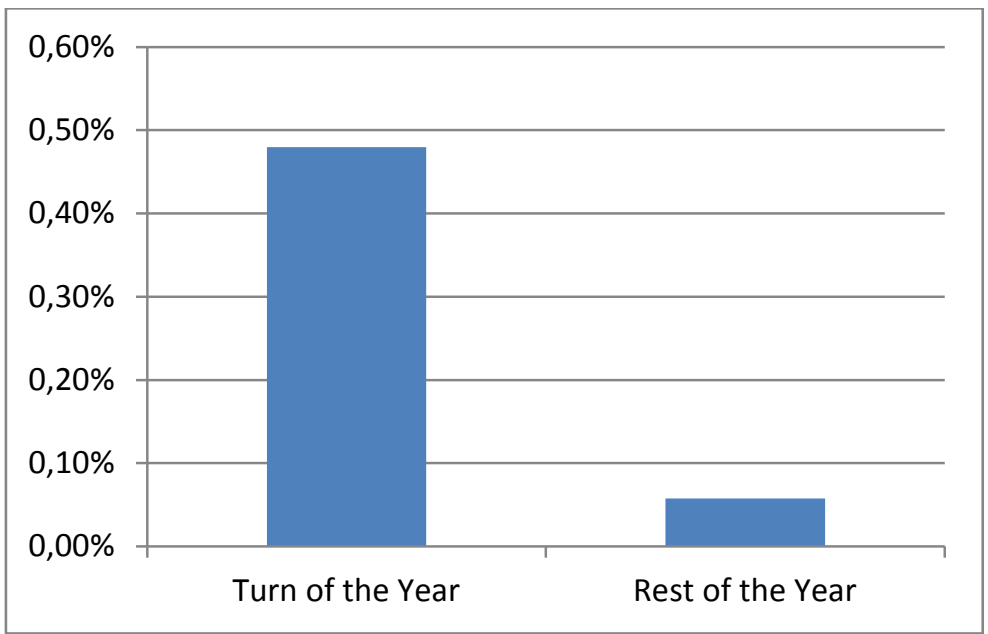

Figure D.1 - Average analysis case of PFTS index

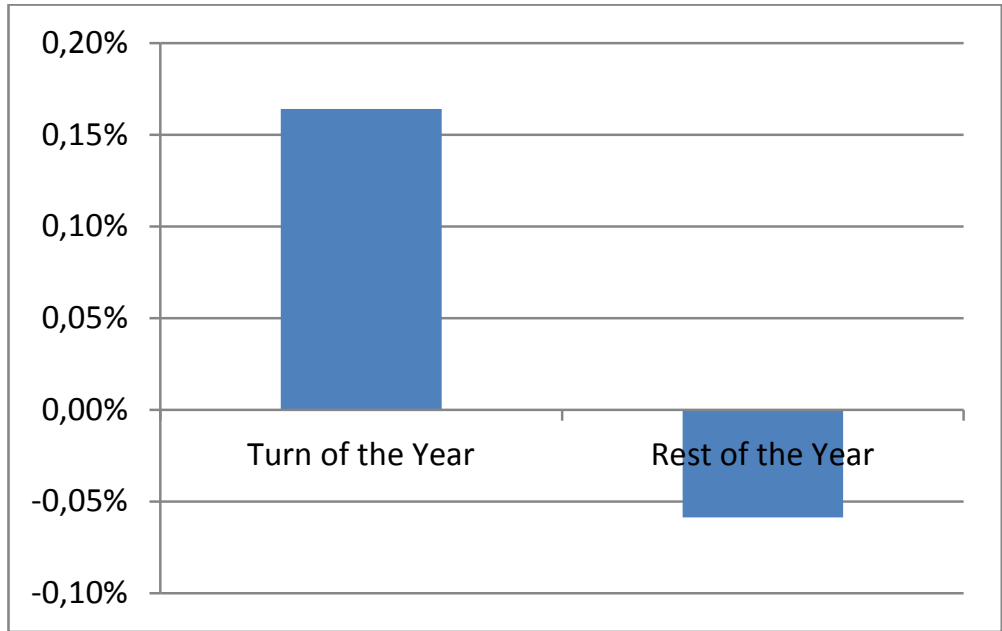

Figure D.2 - Average analysis case of UX index

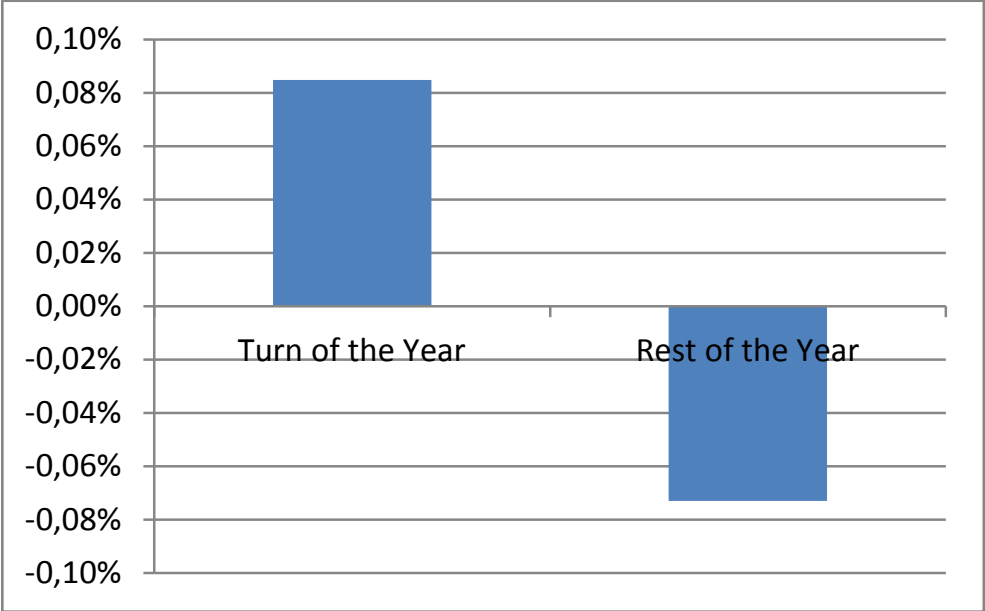

Figure D.3 - Average analysis case of UX futures 
Parametric tests: Student's t-tests

Table D.1: T-test of the Turn of the Year Effect for PFTS index, UX index and UX futures

\begin{tabular}{|l|c|c|c|c|c|c|}
\hline \multirow{2}{*}{ Parameter } & \multicolumn{2}{|c|}{ PFTS index } & \multicolumn{2}{c|}{ UX index } & \multicolumn{2}{c|}{ UX futures } \\
\cline { 2 - 7 } & $\begin{array}{c}\text { Turn of the } \\
\text { Year }\end{array}$ & $\begin{array}{c}\text { Rest of the } \\
\text { Year }\end{array}$ & $\begin{array}{c}\text { Turn of } \\
\text { the Year }\end{array}$ & $\begin{array}{c}\text { Rest of } \\
\text { the Year }\end{array}$ & $\begin{array}{c}\text { Turn of } \\
\text { the Year }\end{array}$ & $\begin{array}{c}\text { Rest of } \\
\text { the Year }\end{array}$ \\
\hline Mean,\% & $0,48 \%$ & $0,06 \%$ & $0,16 \%$ & $-0,06 \%$ & $0,08 \%$ & $-0,07 \%$ \\
\hline Standard deviation,\% & $2,29 \%$ & $1,95 \%$ & $1,35 \%$ & $2,34 \%$ & $1,30 \%$ & $2,28 \%$ \\
\hline Number of observations & 680 & 2840 & 98 & 1898 & 62 & 1345 \\
\hline t-criterion & \multicolumn{2}{|c|}{4.43} & \multicolumn{2}{c|}{1.52} & \multicolumn{2}{c|}{0.89} \\
\hline t-critical $(\mathrm{p}=0,95)$ & \multicolumn{2}{|c|}{1.96} & \multicolumn{2}{c|}{1.96} & \multicolumn{2}{c|}{1.96} \\
\hline Null hypothesis & \multicolumn{2}{|c|}{ Rejected } & \multicolumn{2}{c|}{ Accepted } & \multicolumn{2}{c}{} \\
\hline
\end{tabular}

\section{Parametric tests: ANOVA}

Table D.2: ANOVA test of the Turn of the Year Effect for PFTS index, UX index and UX index

\begin{tabular}{|l|c|c|c|c|}
\hline Instrument & $\mathrm{F}$ & $\mathrm{p}$-value & F critical & Null hypothesis \\
\hline PFTS index & 8,94 & 0,00 & 3,84 & Rejected \\
\hline UX index & 0,87 & 0,35 & 3,85 & Accepted \\
\hline UX futures & 0,29 & 0,59 & 3,85 & Accepted \\
\hline
\end{tabular}

Non-parametric tests: Kruskal-Wallis test

Table D.3: Kruskal -Wallis test of the Turn of the Year Effect for PFTS index, UX index and $U X$ index

\begin{tabular}{|l|c|c|c|c|c|}
\hline Instrument & $\begin{array}{c}\text { Adjusted } \\
\mathrm{H}\end{array}$ & d.f. & P value: & $\begin{array}{c}\text { Critical } \\
\text { value }\end{array}$ & Null hypothesis \\
\hline PFTS index & 4,10 & 1 & 0,04 & 3.84 & Rejected \\
\hline UX index & 0,85 & 1 & 0,36 & 3.84 & Accepted \\
\hline UX futures & 0,51 & 1 & 0,47 & 3.84 & Accepted \\
\hline
\end{tabular}

Regression analysis with dummy variables

Table D.4: Regression analysis with dummy variables of the Turn of the Year Effect for PFTS index, UX index and UX index*

\begin{tabular}{|l|c|c|c|}
\hline \multicolumn{1}{|c|}{ Parameter } & PFTS index & UX index & UX futures \\
\hline Turn of the Year $\left(\mathrm{a}_{0}\right)$ & $\mathbf{0 , 0 0 4 8}$ & & \\
\hline & $\mathbf{( 0 . 0 0 0 8})$ & $0,0016(0.48)$ & $0,0008(0.76)$ \\
Rest of the Year $\left(\mathrm{a}_{1}\right)$ & $\mathbf{- 0 , 0 0 4 4}$ & & \\
\hline F-test & $\mathbf{( 0 . 0 0 2 8})$ & $-0,0022(0.35)$ & $-0,0016(0.59)$ \\
\hline Multiple R & $8,94(0.0028)$ & $0,87(0.35)$ & $0,29(0.59)$ \\
\hline Anomaly & 0,05 & 0,02 & 0,01 \\
\hline
\end{tabular}

* P-values are in parentheses 


\section{Appendix E}

Month of the Year Effect

\section{Empirical results for the Month of the Year Effect}

\section{Average analysis}

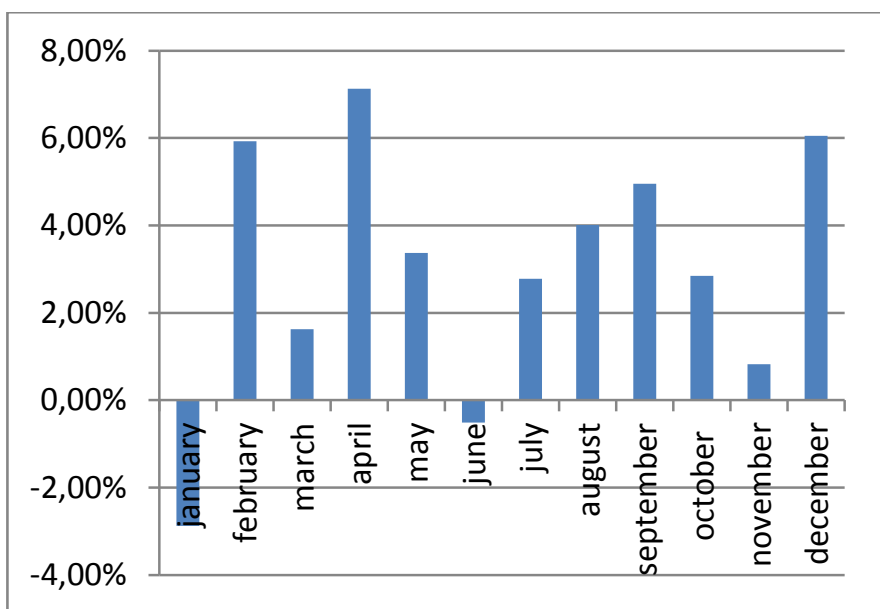

Figure E.1 - Average analysis case of PFTS index

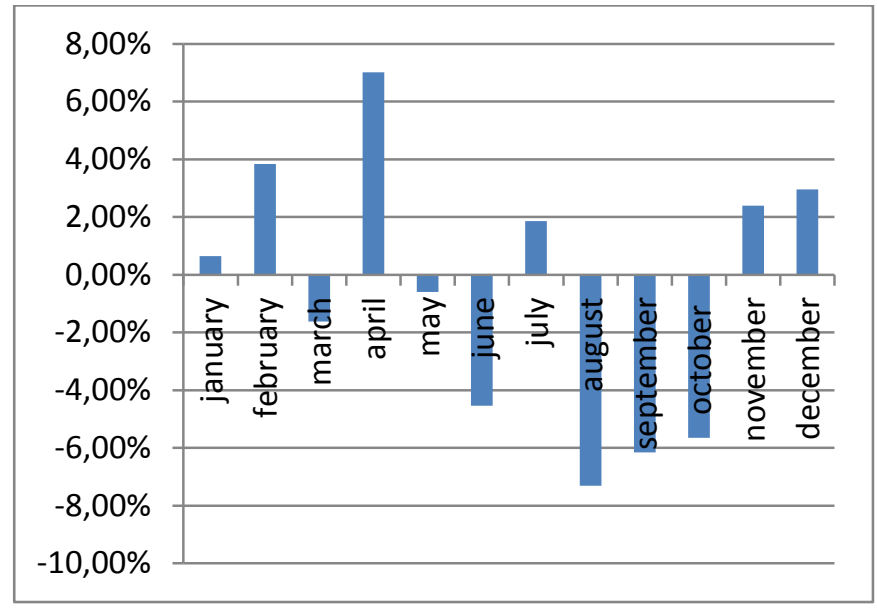

Figure E.2 - Average analysis case of UX index

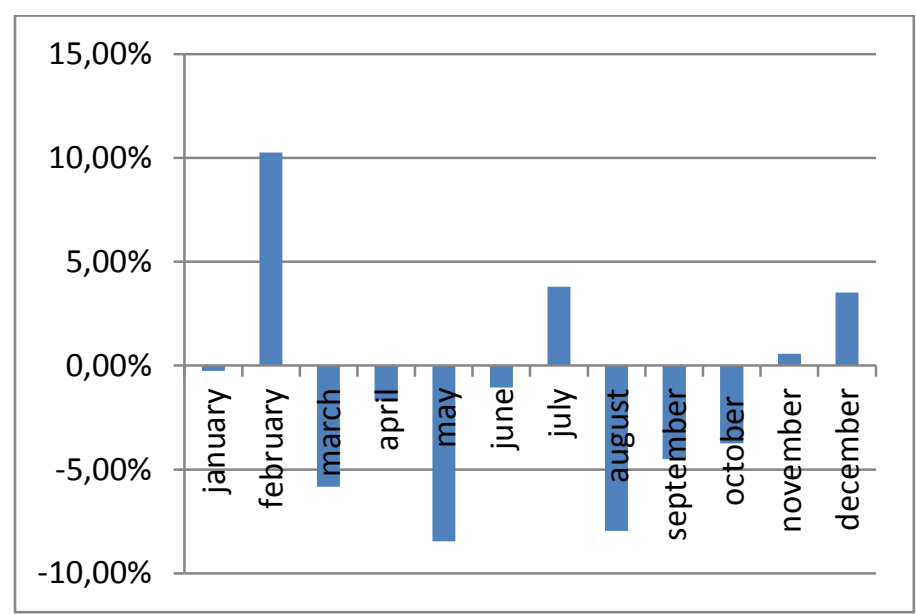

Figure E.3 - Average analysis case of UX futures 


\section{Parametric tests: Student's t-tests}

Table E.1: T-test of the Month of the Year Effect $(t$-critical $(p=0,95)=2.15)$

\begin{tabular}{|l|c|c|c|c|c|c|}
\hline \multirow{2}{*}{ Month } & \multicolumn{2}{|c|}{ PFTS index } & \multicolumn{2}{c|}{ UX index } & \multicolumn{2}{c|}{ UX futures } \\
\cline { 2 - 7 } & t-criterion & $\begin{array}{c}\text { Null } \\
\text { hypothesis }\end{array}$ & t-criterion & $\begin{array}{c}\text { Null } \\
\text { hypothesis }\end{array}$ & t-criterion & $\begin{array}{c}\text { Null } \\
\text { hypothesis }\end{array}$ \\
\hline January & $-1,50$ & Accepted & 0,55 & Accepted & 0,64 & Accepted \\
\hline February & 0,68 & Accepted & 1,11 & Accepted & $\mathbf{4 , 3 0}$ & Rejected \\
\hline March & $-0,43$ & Accepted & $-0,28$ & Accepted & $\mathbf{- 2 , 8 5}$ & Rejected \\
\hline April & 0,92 & Accepted & 1,46 & Accepted & $-0,27$ & Accepted \\
\hline May & 0,17 & Accepted & 0,00 & Accepted & $-1,76$ & Accepted \\
\hline June & $-1,58$ & Accepted & $\mathbf{- 2 , 2 2}$ & Rejected & 0,29 & Accepted \\
\hline July & $-0,08$ & Accepted & 0,98 & Accepted & $\mathbf{3 , 6 8}$ & Rejected \\
\hline August & 0,27 & Accepted & $-\mathbf{2 , 4 2}$ & Rejected & $-\mathbf{3 , 1 2}$ & Rejected \\
\hline September & 0,52 & Accepted & $-1,57$ & Accepted & $-1,52$ & Accepted \\
\hline October & $-0,06$ & Accepted & $-1,71$ & Accepted & $-1,34$ & Accepted \\
\hline November & $-0,91$ & Accepted & 1,12 & Accepted & 0,77 & Accepted \\
\hline December & 0,74 & Accepted & 1,66 & Accepted & 1,51 & Accepted \\
\hline
\end{tabular}

\section{Parametric tests: ANOVA}

Table E.4: ANOVA test of the Month of the Year Effect for PFTS index

\begin{tabular}{|l|c|c|c|c|}
\hline & $\mathrm{F}$ & $\mathrm{p}$-value & F critical & Null hypothesis \\
\hline Overall & 0,67 & 0,77 & 1,85 & Accepted \\
\hline January & 2,03 & 0,17 & 4,23 & Accepted \\
\hline February & 0,44 & 0,51 & 4,23 & Accepted \\
\hline March & 0,16 & 0,69 & 4,23 & Accepted \\
\hline April & 0,77 & 0,39 & 4,23 & Accepted \\
\hline May & 0,02 & 0,88 & 4,23 & Accepted \\
\hline June & 2,46 & 0,13 & 4,23 & Accepted \\
\hline July & 0,00 & 0,95 & 4,23 & Accepted \\
\hline August & 0,07 & 0,80 & 4,23 & Accepted \\
\hline September & 0,25 & 0,62 & 4,23 & Accepted \\
\hline October & 0,00 & 0,96 & 4,23 & Accepted \\
\hline November & 0,66 & 0,43 & 4,23 & Accepted \\
\hline December & 0,51 & 0,48 & 4,23 & Accepted \\
\hline
\end{tabular}


Table E.5: ANOVA test of the Month of the Year Effect for UX index

\begin{tabular}{|l|c|c|c|c|}
\hline & F & p-value & F critical & Null hypothesis \\
\hline Overall & 0,91 & 0,54 & 1,90 & Accepted \\
\hline January & 0,14 & 0,71 & 4,60 & Accepted \\
\hline February & 0,64 & 0,44 & 4,60 & Accepted \\
\hline March & 0,04 & 0,84 & 4,60 & Accepted \\
\hline April & 1,19 & 0,29 & 4,60 & Accepted \\
\hline May & 0,00 & 1,00 & 4,60 & Accepted \\
\hline June & 1,88 & 0,19 & 4,60 & Accepted \\
\hline July & 0,50 & 0,49 & 4,60 & Accepted \\
\hline August & 3,06 & 0,10 & 4,60 & Accepted \\
\hline September & 1,36 & 0,26 & 4,60 & Accepted \\
\hline October & 1,57 & 0,23 & 4,60 & Accepted \\
\hline November & 0,61 & 0,45 & 4,60 & Accepted \\
\hline December & 1,30 & 0,27 & 4,60 & Accepted \\
\hline
\end{tabular}

Table E.6: ANOVA test of the Month of the Year Effect for UX futures

\begin{tabular}{|l|c|c|c|c|}
\hline & $\mathrm{F}$ & $\mathrm{p}$-value & F critical & Null hypothesis \\
\hline Overall & 2,03 & 0,04 & 1,96 & Accepted \\
\hline January & 0,16 & 0,69 & 5,12 & Accepted \\
\hline February & $\mathbf{8 , 0 8}$ & $\mathbf{0 , 0 2}$ & $\mathbf{5 , 1 2}$ & Rejected \\
\hline March & 3,59 & 0,09 & 5,12 & Accepted \\
\hline April & 0,06 & 0,81 & 4,96 & Accepted \\
\hline May & 1,39 & 0,27 & 4,96 & Accepted \\
\hline June & 0,05 & 0,83 & 4,96 & Accepted \\
\hline July & $\mathbf{6 , 4 4}$ & $\mathbf{0 , 0 3}$ & $\mathbf{4 , 9 6}$ & Rejected \\
\hline August & 4,38 & 0,06 & 4,96 & Accepted \\
\hline September & 1,08 & 0,32 & 4,96 & Accepted \\
\hline October & 0,89 & 0,37 & 4,96 & Accepted \\
\hline November & 0,25 & 0,63 & 4,96 & Accepted \\
\hline December & 0,99 & 0,34 & 4,96 & Accepted \\
\hline
\end{tabular}


Non-parametric tests: Kruskal-Wallis test

Table E.7: Kruskal-Wallis test of the Month of the Year Effect for PFTS index

\begin{tabular}{|l|c|c|c|c|c|}
\hline & $\begin{array}{c}\text { Adjusted } \\
\mathrm{H}\end{array}$ & d.f. & P value & Critical value & Null hypothesis \\
\hline Overall & 8,09 & 11 & 0,71 & 19,68 & Accepted \\
\hline January & $\mathbf{4 , 0 9}$ & $\mathbf{1}$ & $\mathbf{0 , 0 4}$ & $\mathbf{3 , 8 4}$ & Rejected \\
\hline February & 0,41 & 1 & 0,52 & 3,84 & Accepted \\
\hline March & 0,00 & 1 & 0,96 & 3,84 & Accepted \\
\hline April & 0,14 & 1 & 0,71 & 3,84 & Accepted \\
\hline May & 0,21 & 1 & 0,65 & 3,84 & Accepted \\
\hline June & 3,21 & 1 & 0,07 & 3,84 & Accepted \\
\hline July & 0,30 & 1 & 0,58 & 3,84 & Accepted \\
\hline August & 0,54 & 1 & 0,46 & 3,84 & Accepted \\
\hline September & 0,03 & 1 & 0,85 & 3,84 & Accepted \\
\hline October & 0,01 & 1 & 0,93 & 3,84 & Accepted \\
\hline November & 0,76 & 1 & 0,38 & 3,84 & Accepted \\
\hline December & 0,01 & 1 & 0,93 & 3,84 & Accepted \\
\hline
\end{tabular}

Table E.8: Kruskal-Wallis test of the Month of the Year Effect for UX index

\begin{tabular}{|l|c|c|c|c|c|}
\hline & $\begin{array}{c}\text { Adjusted } \\
\mathrm{H}\end{array}$ & d.f. & P value & Critical value & Null hypothesis \\
\hline Overall & 12,76 & 11 & 0,31 & 19,68 & Accepted \\
\hline January & 0,04 & 1 & 0,83 & 3,84 & Accepted \\
\hline February & 2,48 & 1 & 0,12 & 3,84 & Accepted \\
\hline March & 1,33 & 1 & 0,25 & 3,84 & Accepted \\
\hline April & 0,89 & 1 & 0,34 & 3,84 & Accepted \\
\hline May & 0,01 & 1 & 0,92 & 3,84 & Accepted \\
\hline June & 1,10 & 1 & 0,29 & 3,84 & Accepted \\
\hline July & 1,33 & 1 & 0,25 & 3,84 & Accepted \\
\hline August & 2,82 & 1 & 0,09 & 3,84 & Accepted \\
\hline September & 1,10 & 1 & 0,29 & 3,84 & Accepted \\
\hline October & 0,71 & 1 & 0,40 & 3,84 & Accepted \\
\hline November & 0,71 & 1 & 0,40 & 3,84 & Accepted \\
\hline December & 0,89 & 1 & 0,34 & 3,84 & Accepted \\
\hline
\end{tabular}


Table E.9: Kruskal-Wallis test of the Month of the Year Effect for UX futures

\begin{tabular}{|l|c|c|c|c|c|}
\hline & $\begin{array}{c}\text { Adjusted } \\
\mathrm{H}\end{array}$ & d.f. & P value & Critical value & Null hypothesis \\
\hline Overall & 19,39 & 11 & 0,05 & 19,68 & Accepted \\
\hline January & 0,01 & 1 & 0,92 & 3,84 & Accepted \\
\hline February & $\mathbf{4 , 8 0}$ & $\mathbf{1}$ & $\mathbf{0 , 0 3}$ & $\mathbf{3 , 8 4}$ & Rejected \\
\hline March & 1,32 & 1 & 0,25 & 3,84 & Accepted \\
\hline April & 0,03 & 1 & 0,87 & 3,84 & Accepted \\
\hline May & 1,26 & 1 & 0,26 & 3,84 & Accepted \\
\hline June & 0,41 & 1 & 0,52 & 3,84 & Accepted \\
\hline July & 3,69 & 1 & 0,05 & 3,84 & Accepted \\
\hline August & $\mathbf{5 , 0 3}$ & $\mathbf{1}$ & $\mathbf{0 , 0 2}$ & $\mathbf{3 , 8 4}$ & Rejected \\
\hline September & 0,92 & 1 & 0,34 & 3,84 & Accepted \\
\hline October & 0,10 & 1 & 0,75 & 3,84 & Accepted \\
\hline November & 1,26 & 1 & 0,26 & 3,84 & Accepted \\
\hline December & 0,92 & 1 & 0,34 & 3,84 & Accepted \\
\hline
\end{tabular}

Regression analysis with dummy variables

Table E.10: Regression analysis with dummy variables of the Month of the Year Effect for PFTS index, UX index and UX futures *

\begin{tabular}{|c|c|c|c|}
\hline Parameter & PFTS index & UX index & UX futures \\
\hline January $\left(\mathrm{a}_{0}\right)$ & $-0,0288(0.4215)$ & $0,0065(0.8920)$ & $-0,0025(0.9504)$ \\
\hline February $\left(a_{1}\right)$ & $0,0880(0.0832)$ & $0,0318(0.6363)$ & $0,1051(0.0666)$ \\
\hline $\operatorname{March}\left(\mathrm{a}_{2}\right)$ & $0,0450(0.3737)$ & $-0,0227(0.7363)$ & $-0,0558(0.3244)$ \\
\hline April $\left(a_{3}\right)$ & $0,1000(0.0493)$ & $0,0636(0.3457)$ & $-0,0143(0.7912)$ \\
\hline May $\left(a_{4}\right)$ & $0,0624(0.2185)$ & $-0,0125(0.8531)$ & $-0,0820(0.1331)$ \\
\hline June $\left(a_{5}\right)$ & $0,0237(0.6401)$ & $-0,0519(0.4413)$ & $-0,0080(0.8820)$ \\
\hline July $\left(a_{6}\right)$ & $0,0566(0.2642)$ & $0,0120(0.8580)$ & $0,0406(0.4540)$ \\
\hline August $\left(\mathrm{a}_{7}\right)$ & $0,0688(0.1748)$ & $-0,0795(0.2393)$ & $-0,0770(0.1580)$ \\
\hline September $\left(\mathrm{a}_{8}\right)$ & $0,0783(0.1230)$ & $-0,0681(0.3131)$ & $-0,0425(0.4329)$ \\
\hline October $\left(\mathrm{a}_{9}\right)$ & $0,0572(0.2589)$ & $-0,0630(0.3501)$ & $-0,0350(0.5178)$ \\
\hline November $\left(\mathrm{a}_{10}\right)$ & $0,0370(0.4645)$ & $0,0175(0.7950)$ & $0,0082(0.8798)$ \\
\hline December $\left(a_{11}\right)$ & $0,0893(0.0789)$ & $0,0231(0.7319)$ & 0,0377 (0.4559) \\
\hline F-test & $0,67(0.7685)$ & $0,91(0.5367)$ & $2,03(0.0418)$ \\
\hline Multiple R & 0,21 & 0,33 & 0,53 \\
\hline Anomaly & $\begin{array}{c}\text { Partially } \\
\text { confirmed }\end{array}$ & Not confirmed & Not confirmed \\
\hline
\end{tabular}




\section{Appendix F}

\section{Empirical results for the Holiday Effect}

\section{Average analysis}

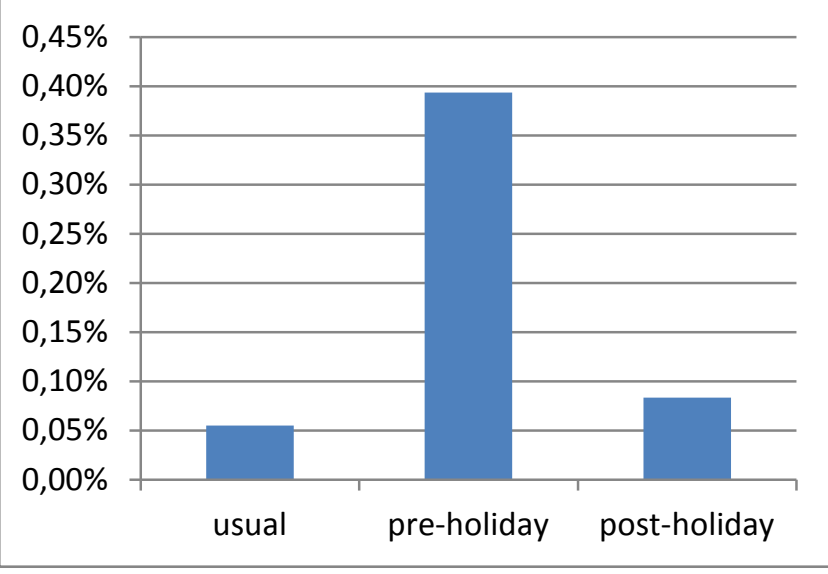

Figure F.1 - Average analysis case of PFTS index

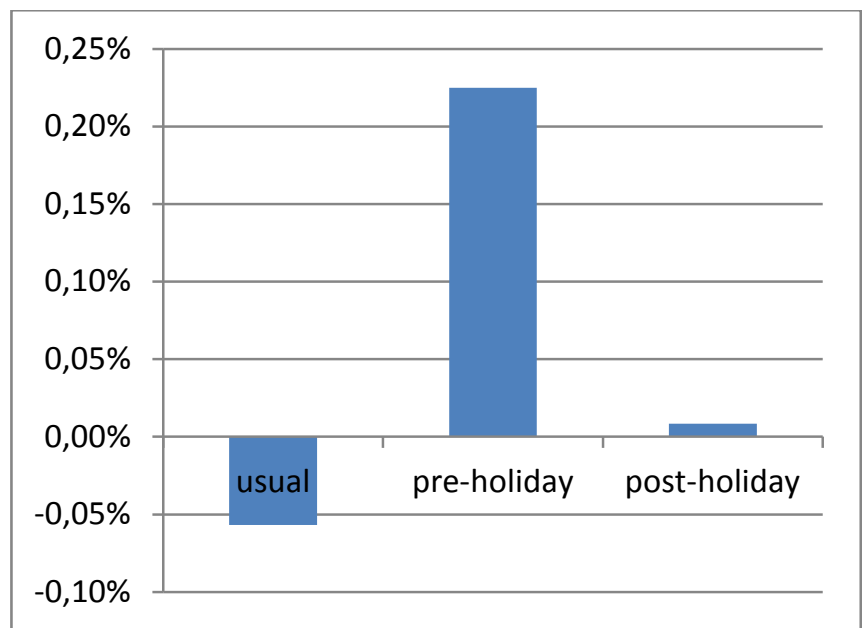

Figure F.2 - Average analysis case of UX index

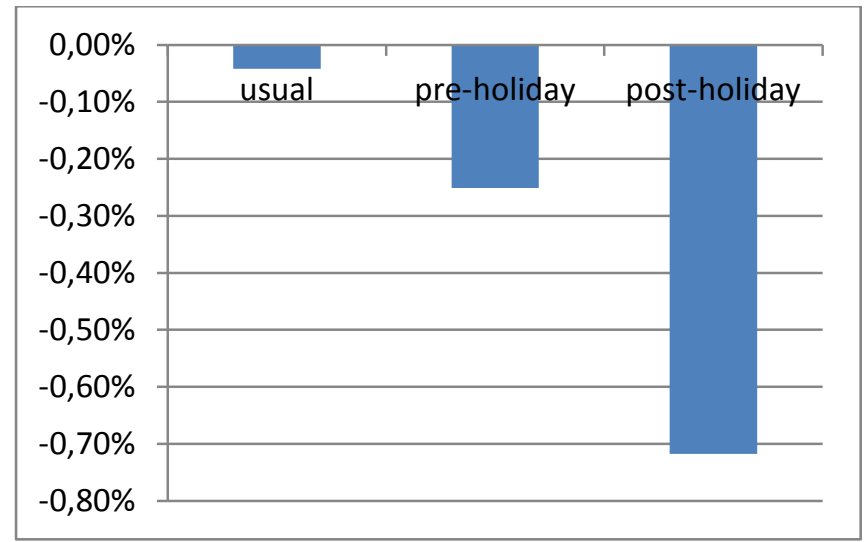

Figure F.3 - Average analysis case of UX futures 
Table F.1: T-test of the Holiday Effect for PFTS index, UX index and UX futures (tcritical $(p=0,95)=1.96)$

\begin{tabular}{|l|c|c|c|c|c|c|}
\hline \multirow{2}{*}{ Parameter } & \multicolumn{2}{|c|}{ PFTS index } & \multicolumn{2}{c|}{ UX index } & \multicolumn{2}{c|}{ UX futures } \\
\cline { 2 - 7 } & t-criterion & $\begin{array}{c}\text { Null } \\
\text { hypothesis }\end{array}$ & t-criterion & $\begin{array}{c}\text { Null } \\
\text { hypothesis }\end{array}$ & t-criterion & $\begin{array}{c}\text { Null } \\
\text { hypothesis }\end{array}$ \\
\hline Pre-holiday & 1,10 & Accepted & 1,04 & Accepted & 0,98 & Accepted \\
\hline Post-holiday & 0,12 & Accepted & 0,15 & Accepted & $-1,70$ & Accepted \\
\hline
\end{tabular}

\section{Parametric tests: ANOVA}

Table F.2: ANOVA test of the Holiday Effect for PFTS index, UX index and UX futures

\begin{tabular}{|l|c|c|c|c|}
\hline Instrument & $\mathrm{F}$ & $\mathrm{p}$-value & F critical & Null hypothesis \\
\hline PFTS index & 1,37 & 0,25 & 3,00 & Accepted \\
\hline UX index & 0,40 & 0,67 & 3,00 & Accepted \\
\hline UX futures & 1,81 & 0,16 & 3,00 & Accepted \\
\hline
\end{tabular}

Non-parametric tests: Kruskal -Wallis test

Table F.3: Kruskal -Wallis test of the Holiday Effect for PFTS index, UX index and UX futures

\begin{tabular}{|l|c|c|c|c|c|}
\hline Instrument & $\begin{array}{c}\text { Adjusted } \\
\mathrm{H}\end{array}$ & d.f. & P value: & $\begin{array}{c}\text { Critical } \\
\text { value }\end{array}$ & Null hypothesis \\
\hline PFTS index & 0,08 & 2 & 0,96 & 5,99 & Accepted \\
\hline UX index & 1,74 & 2 & 0,42 & 5,99 & Accepted \\
\hline UX futures & 5,33 & 2 & 0,07 & 5,99 & Accepted \\
\hline
\end{tabular}

Regression analysis with dummy variables

Table F.4: Regression analysis with dummy variables of the Holiday Effect for PFTS index, UX index and UX futures *

\begin{tabular}{|l|c|c|c|}
\hline \multicolumn{1}{|c|}{ Parameter } & PFTS index & UX index & UX futures \\
\hline Usual $\left(\mathrm{a}_{0}\right)$ & $0,0006(0.10)$ & $-0,0006(0.28)$ & $-0,0004(0.49)$ \\
\hline Pre-holiday $\left(\mathrm{a}_{1}\right)$ & $0,0034(0.10)$ & $0,0028(0.38)$ & $-0,0021(0.57)$ \\
\hline Post-holiday $\left(\mathrm{a}_{2}\right)$ & $0,0003(0.89)$ & $0,0007(0.84)$ & $-0,0068(0.07)$ \\
\hline F-test & $1,37(0.25)$ & $0,40(0.67)$ & $1,81(0.16)$ \\
\hline Multiple R & 0,03 & 0,02 & 0,05 \\
\hline Anomaly & Not confirmed & Not confirmed & Not confirmed \\
\hline
\end{tabular}




\section{Appendix G}

\section{Empirical results for the Halloween Effect}

\section{Average analysis}

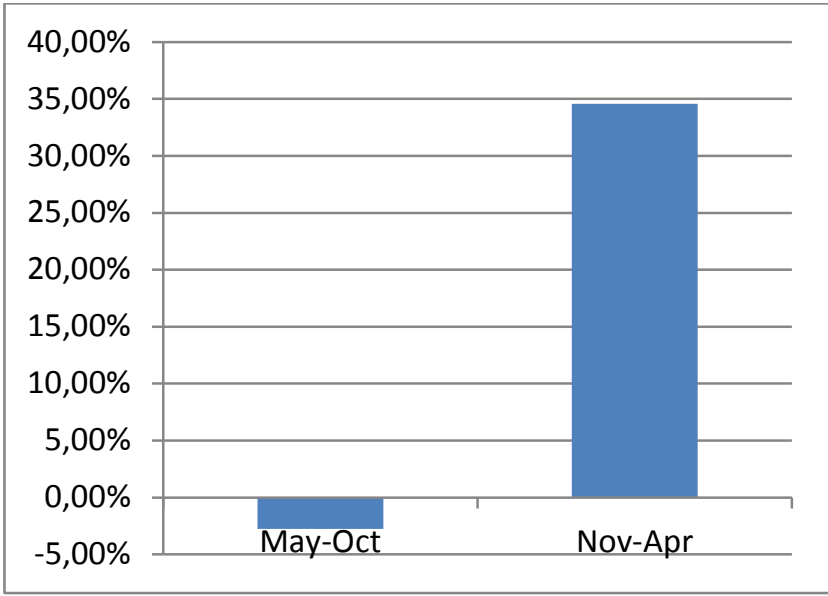

Figure G.1 - Average analysis case of PFTS index

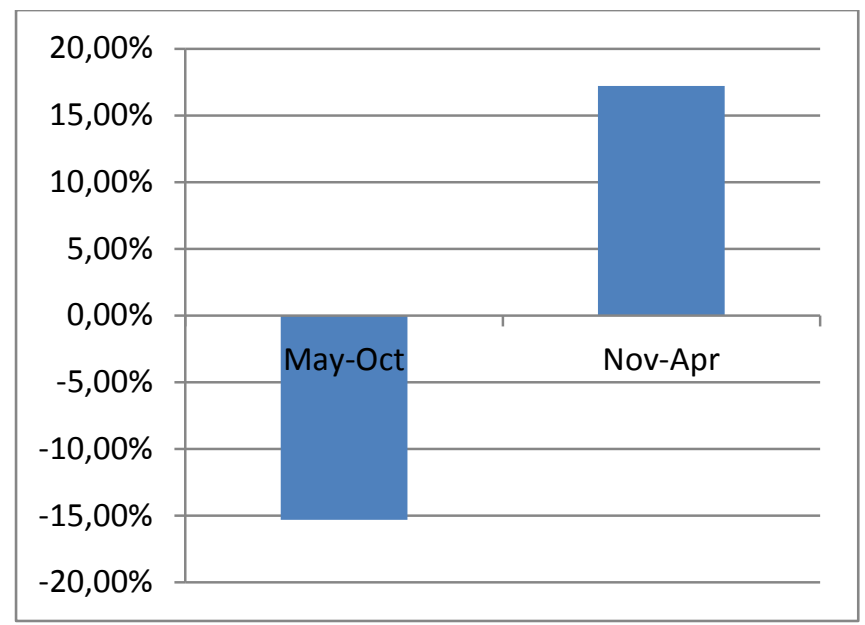

Figure G.2 - Average analysis case of UX index

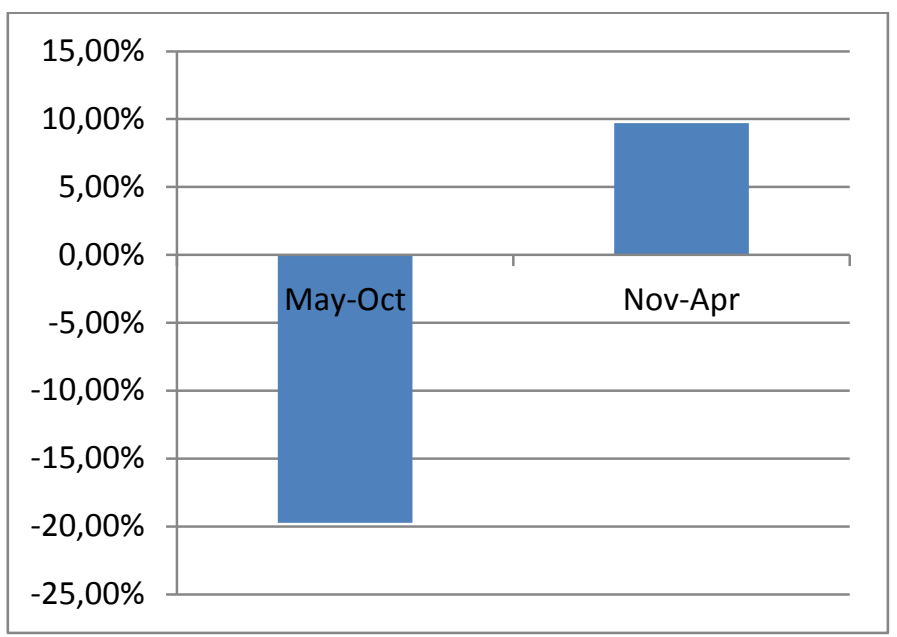

Figure G.3 - Average analysis case of UX futures 
Parametric tests: Student's t-test

Table G.1: T-test of the Halloween Effect for PFTS index, UX index and UX futures

\begin{tabular}{|c|c|c|c|c|c|c|}
\hline Instrument & \multicolumn{2}{|c|}{ PFTS index } & \multicolumn{2}{|c|}{ UX index } & \multicolumn{2}{|c|}{ UX futures } \\
\hline Parameter & May-Oct & Nov-Apr & May-Oct & Nov-Apr & May-Oct & Nov-Apr \\
\hline Mean,\% & $-2,73 \%$ & $34,58 \%$ & $-15,30 \%$ & $17,21 \%$ & $-19,73 \%$ & $9,70 \%$ \\
\hline Standard deviation,\% & $38,50 \%$ & $43,31 \%$ & $44,55 \%$ & $34,34 \%$ & $22,27 \%$ & $23,53 \%$ \\
\hline Number of observations & 14 & 14 & 8 & 8 & 6 & 5 \\
\hline t-criterion & \multicolumn{2}{|c|}{2.41} & \multicolumn{2}{|c|}{1.63} & \multicolumn{2}{|c|}{2.11} \\
\hline t-critical $(p=0,95)$ & \multicolumn{2}{|c|}{2.14} & \multicolumn{2}{|c|}{2.3} & \multicolumn{2}{|c|}{2.45} \\
\hline Null hypothesis & \multicolumn{2}{|c|}{ Rejected } & \multicolumn{2}{|c|}{ Accepted } & \multicolumn{2}{|c|}{ Accepted } \\
\hline
\end{tabular}

\section{Parametric tests: ANOVA}

Table G.2: ANOVA test of the Month of the Year Effect for PFTS index

\begin{tabular}{|l|c|c|c|c|}
\hline Instrument & $\mathrm{F}$ & $\mathrm{p}$-value & F critical & Null hypothesis \\
\hline PFTS index & 5,80 & 0,02 & 4,23 & Rejected \\
\hline UX index & 2,67 & 0,12 & 4,60 & Accepted \\
\hline UX futures & 4,53 & 0,06 & 5,12 & Accepted \\
\hline
\end{tabular}

Non-parametric tests: Kruskal -Wallis test

Table G.3: Kruskal -Wallis test of the Holiday Effect for PFTS index, UX index and UX futures

\begin{tabular}{|l|c|c|c|c|c|}
\hline Instrument & $\begin{array}{c}\text { Adjusted } \\
\mathrm{H}\end{array}$ & d.f. & P value: & $\begin{array}{c}\text { Critical } \\
\text { value }\end{array}$ & Null hypothesis \\
\hline PFTS index & 3,55 & 1 & 0,06 & 3,84 & Accepted \\
\hline UX index & 3,19 & 1 & 0,07 & 3,84 & Accepted \\
\hline UX futures & 2,70 & 1 & 0,10 & 3,84 & Accepted \\
\hline
\end{tabular}

\section{Regression analysis with dummy variables}

Table G.4: Regression analysis with dummy variables of the Holiday Effect for PFTS index, UX index and UX futures *

\begin{tabular}{|l|c|c|c|}
\hline \multicolumn{1}{|c|}{ Parameter } & PFTS index & UX index & UX futures \\
\hline May-Oct $\left(\mathrm{a}_{0}\right)$ & $-0,03(0.80)$ & $-0,15(0.29)$ & $-0,20(0,06)$ \\
\hline Nov-Apr $\left(\mathrm{a}_{1}\right)$ & $\mathbf{0 , 3 7 ( \mathbf { 0 . 0 2 } )}$ & $0,33(0.12)$ & $0,29(0,06)$ \\
\hline F-test & $5,80(0.02)$ & $2,67(0.12)$ & $4,53(0,06)$ \\
\hline Multiple R & 0,43 & 0,40 & 0,58 \\
\hline Anomaly & Confirmed & Not confirmed & Not confirmed \\
\hline
\end{tabular}

* P-values are in parentheses 